\title{
Local delivery of nitric oxide: targeted delivery of therapeutics to bone and connective tissues
}

\author{
Scott P. Nichols ${ }^{1}$, Wesley L. Storm ${ }^{1}$, Ahyeon Koh, and Mark H. Schoenfisch ${ }^{*}$ \\ Department of Chemistry, University of North Carolina at Chapel Hill, Chapel Hill, North Carolina \\ 27599, USA
}

\begin{abstract}
Non-invasive treatment of injuries and disorders affecting bones and connective tissue is a significant challenge facing the medical community. A treatment route that has recently been proposed is nitric oxide (NO) therapy. Nitric oxide plays several roles in physiology with many conditions lacking adequate levels of NO. As NO is a radical, localized delivery via NO donors is essential to promoting biological activity. Herein, we review current literature related to therapeutic NO delivery in the treatment of bone, skin and tendon repair.
\end{abstract}

\section{Keywords}

Wound healin; tendon repair; diabetes; osteoporosis; S-nitrosothiol; N-diazeniumdiolate; organic nitrate; collagen; osteoblast; osteoclast

\section{Introduction}

Musculoskeletal disorders (e.g., arthritis, osteoporosis, and inflammatory bone disease) are a major health concern in the U.S. due to an aging population and increased occurrence of sports-related injuries. In addition, roughly 4.4 million people are expected to have one or more internal fixation devices, of which $\sim 3 \%$ will become infected $[1,2]$. Osteoporosis, caused by local or systemic bone loss, occurs most commonly in women after age 40 with estrogen deficiency due to menopause [3]. Conditions such as osteoporosis lead to bone fracture and tendon damage. Subsequent wound healing and tendon healing are complex processes that involve the proliferation and differentiation of bone cells (e.g., osteoblasts) during development, followed by the production of extracellular matrices in response to normal and abnormal physiological situations [4,5]. Moreover, extreme calcium loss and increases in bone resorption have been linked to several cancers (e.g., bone metastases of breast and prostate tumors) [3]. While certain drugs (e.g., estrogen and selective estrogen receptors) are beneficial in inhibiting the formation or activity of osteoclasts, undesirable side effects limit their long-term use and thus necessitate localized therapeutics. Other

\footnotetext{
(C) 2012 Elsevier B.V. All rights reserved

*Corresponding author Mark H. Schoenfisch Ph.D. Chemistry University of North Carolina at Chapel Hill, Department of Chemistry, CB\#3290, Chapel Hill, North Carolina, 27599, USA Tel: +1 (919) 843-8714 Fax: +1 (919) 962-2388 schoenfisch@unc.edu.

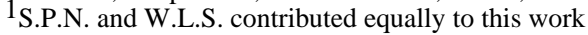

Scott P. Nichols snichols@unc.edu

Wesley L.Storm wstorm@email.unc.edu

Ahyeon Koh ahyeon@email.unc.edu

Publisher's Disclaimer: This is a PDF file of an unedited manuscript that has been accepted for publication. As a service to our customers we are providing this early version of the manuscript. The manuscript will undergo copyediting, typesetting, and review of the resulting proof before it is published in its final citable form. Please note that during the production process errors may be discovered which could affect the content, and all legal disclaimers that apply to the journal pertain.
} 
treatments for musculoskeletal disorders (e.g., injuries to bone, ligaments, and joints) are based on the use of grafts from existing tissue or implantation of prosthetic devices. Although fairly successful, invasive orthopedic surgeries still result in poor host tissue response and microbial infection, particularly for open-fracture boned and joint-revision surgeries $[2,6]$. Thus, molecules that mediate bone formation, resorption and repair, wound healing, and anti-microbial action at implants have been proposed as candidates for targeted and localized delivery therapeutics.

Nitric oxide (NO) is an endogenously produced diatomic molecule and that plays multiple roles in physiological process, including angiogenesis, wound healing, neurotransmission, smooth muscle relaxation, and inflammation [7]. Nitric oxide's action on physiology is highly dependent on location, source, and concentration [7, 8]. Nitric oxide is produced in vivo by NO synthase (NOS), an enzyme that catalyzes the oxidation of a guanidine nitrogen from L-arginine in the presence of calcium ions, NADH, and tetrahydrobiopterin as cofactors [7, 8]. Endothelial NOS (eNOS), inducible NOS (iNOS), and neuronal NOS (nNOS) are the three distinct NOS isoforms. [9] Low nanomolar NO concentrations are produced by eNOS and nNOS to promote vasodilation and neurotransmission, respectively [9]. The iNOS form is capable of producing micromolar levels of NO, often in response to infection and inflammation [9]. Nitric oxide has a short half-life $(<1 \mathrm{~s}$ in the presence of oxygen and hemoglobin) in vivo, arising from its high reactivity with transition metals, heme-containing proteins, and thiols [7]. As such, NO's sphere of influence is limited to a few $\mu \mathrm{m}$ [10]. In the presence of superoxide $\left(\mathrm{O}_{2}{ }^{-}\right)$, $\mathrm{NO}$ will react to form peroxynitrite $\left(\mathrm{ONOO}^{-}\right)$, an even greater oxidant involved in the inflammatory response [11]. Due to the reactive nature of gaseous NO, chemical strategies for NO storage and release have been developed in an effort to capture NO's pharmacological potential.

\section{Nitric oxide donors}

Multiple NO donor types exist with unique NO release triggers and kinetics. $N$ diazeniumdiolates (1-amino-substitutied diazen-1-ium-1,2-diolate) and $S$-nitrosothiols represent the two most diverse NO donor classes. $N$-diazeniumdiolates form on secondary amines under high pressures of NO in the presence of base. Upon proton initiated degradation (e.g., in water), the NO donor releases two molecules of NO per secondary amine (Figure 1) [12,13]. $S$-nitrosothiols are an endogenous NO carrier but may be synthesized on free thiol groups upon exposure to a nitrosating agent (e.g., nitrous acid) [14]. Nitric oxide release of the sulfur-bound NO may be initiated by heat, light, or exposure to copper ion (Figure 1) [14]. Additionally, transnitrosation may occur resulting in the transfer of the S-nitrosothiol group to another free thiol group [14]. Both of these NO donors have the advantage of spontaneously releasing NO without the need of other agents (e.g., enzymes). For example, small molecular weight NO donors that have been synthesized and used in biological studies include (Z)-1-[N-(3-aminopropyl)- $N$-(n-propyl)amino $]$ diazen-1ium-1,2-diolate (PAPA/NO), 1-[ $N$-(aminoethyl)- $N$-(2-ammonioethyl)amino] diazen-1ium-1,2-diolate (DETA/NO), $S$-nitrosoglutathione (GSNO), and $S$-nitroso- $N$-acetylpenicillamine (SNAP) $[15,16]$. To enhance NO payloads and/or expand the utility of NO release, macromolecular NO release scaffolds have been developed with similar NO donor chemistry. Materials spanning xerogels [1, 11, 17], silica nanoparticles [18-20], dendrimers $[21,22]$, synthetic polymers [23-25], and electrospun fibers [26] have been reported.

Among the NO donors already used clinically, organic nitrates have been most widely employed [27], with their use dating to the 1870s [28], While the release of NO from organic nitrates is invoked without the assistance of enzymes to some extent, the primary mechanism of NO production is enzymatic (Figure 1) [27]. For example, nitroglycerin, the most commonly used organic nitrate, primarily "releases" NO upon bioactivation by 
mitochondrial aldehyde dehydrogenase (mtALDH) [29, 30]. Unfortunately, patients often develop a tolerance to nitroglycerin due in part by inactivation of mtALDH in response to oxidative stress [31,32], thus limiting the NO-donating capacity of nitroglycerin, reducing treatment efficacy and complicating clinical results. Despite these potential shortcomings, much NO release-related clinical research data is based on nitroglycerin.

Metal nitrosyl compounds represent another class of compounds used to generate NO in biological studies. Two examples of metal nitrosyls are sodium nitroprusside $\left(\mathrm{Na}_{2}\left[\mathrm{Fe}(\mathrm{CN})_{5} \mathrm{NO}\right], \mathrm{SNP}\right)$ and potassium nitrosylpentachlororuthenate $\left(\mathrm{K}_{2}\left[\mathrm{Ru}(\mathrm{NO}) \mathrm{Cl}_{5}\right]\right.$, NPR), with SNP being the most common [27, 33]. For 70 years, SNP has been used to reduce blood pressure in hypertensive emergencies [27]. Metal nitrosyls are capable of releasing NO enzymatically, non-enzymatically when in the presence of vascular tissue and reducing agents (e.g., ascorbic acid), or by light irradiation [27, 34, 35]. However, cellular toxicity is a concern for SNP use due to the liberation of cyanide and the formation of cytotoxic peroxynitrite upon the release of NO [27]. Structures for the metal nitrosyl compounds and other NO-releasing materials discussed are provided in Figure 2.

The NO release kinetics and total payloads for common NO donors are shown in Table 1. While the NO release mechanism for $\mathrm{N}$-diazeniumdiolates is well understood, NO release for $S$-nitrosothiols, organic nitrates, and metal nitrosyls are highly dependent on a number of factors including enzymes, free thiols, and light. Therefore, the NO release kinetics of these donors vary significantly, particularly in vitro vs. in vivo, and thus are excluded from Table 1 .

Based on recent research demonstrating the utility of NO release as an antibacterial and wound healing promoting agent, the localized delivery of NO using NO donors represents a promising strategy for reducing implant-associated infections and promoting tissue regeneration in the orthopedic arena. The risk of systemic toxicity and undesirable side effects may be mitigated by careful selection of NO donors. Next, we detail the role of NO in bone formation, resorption, and repair.

\section{Nitric oxide delivery to bone}

\subsection{Roles of NO in bone tissue}

Bone is a complex, dynamic, living tissue that undergoes constant remodeling carried out by osteoblasts and osteoclasts that deposit new bone and remove existing mineralized bone and organic tissue, respectively [36]. Imbalances in bone turnover result in a variety of medical conditions. For example, the over-activity of osteoclasts amplifies bone loss in postmenopausal osteoporosis, while reduced osteoclastic activity is a major contributor to osteopetrosis, a condition characterized by excess mineralized bone.

Nitric oxide is involved in the cellular processes responsible for bone turnover. Constitutively generated by eNOS, NO contributes to the proliferation and differentiation of osteoblasts [37]. When eNOS is specifically targeted for disruption in mice, osteoblasts cultured from their tissue show inhibited proliferation and decreased activity [37, 38]. Nitric oxide also plays a pivotal role in osteoclastic activity as decreased NO levels have been shown to enhance osteoclastogenesis and associated bone resorption [39]. This effect appears to be biphasic, as high concentrations of NO inhibit cytokines that contribute to bone resorption whereas low concentrations potentiate their effect.[40] Nitric oxide may play a part in the multinucleation of osteoclasts as evidenced by elevated NO levels in preosteoclasts prior to cell fusion [41]. 
Nitric oxide expression by bone cells is in part regulated by sex hormones such as estrogen. One such estrogen, 17 $\beta$-estradiol, promotes apoptosis of osteoclasts by inhibiting bone resorption [42]. In osteoblasts, exposure to $17 \beta$-estradiol upregulates eNOS [43]. Constitutive NO production stimulated by eNOS then promotes proliferation and differentiation of osteoblasts, resulting in increased bone deposition [44]. Targeted disruption of eNOS in mice nullifies the beneficial effects of exogenously supplied estrogen, suggesting that $\mathrm{NO}$ is a significant factor in estrogen-promoted bone formation [45]. These findings have guided research efforts towards NO therapy as a treatment for postmenopausal osteoporosis when estrogen levels are depressed [46].

The activity of all three NOS isoforms is increased following fracture in humans and rats, indicating NO is also involved in bone fracture repair [47, 48]. Diwan et al. found that iNOS levels increased $4 \mathrm{~d}$ after fracture, proceeded by a delayed increase in eNOS and nNOS expression [47]. Rats supplemented with L- $N$-nitroarginine methyl ester (L-NAME), a non-specific NOS inhibitor, experienced inhibited fracture healing as evidenced by a reduction in the cross-sectional area and failure load of explanted femurs. Evaluating the role of iNOS specifically in fracture healing through targeted gene deletion illustrated that femurs from iNOS deficient mice had a decreased total and maximum energy absorption following fracture, although the biomechanical properties remained unaffected [48].

Mechanical strain at forces lower than those necessary for fracture also stimulates NO production, ultimately helping bone adapt to its functional needs [49]. As a way to regulate the constant remodeling necessary for this process, mechanical strain on osteoclast progenitor cells increases local NO concentrations by upregulating eNOS and consequently reducing osteoclastic activity $[49,50]$. Osteoblasts also respond to strain and shear stress through the activation of protein kinase by cyclic guanasine monophosphate (cGMP), a species activated by NO released in response to strain [51]. Bone resorption is also controlled through suppression of the receptor activator of nuclear factor kappa-B ligand (RANKL) [52], a member of the tumor necrosis factor family and an essential factor for osteoclastogenesis. Interestingly, chemically-induced inhibition of nNOS and eNOS in mechanically strained stromal cells reversed the inhibition of RANKL associated with strain [53]. Although experiments in eNOS deficient mice demonstrate that alternative pathways for RANKL inhibition still exist, this suggests that RANKL inhibition is in part mediated by NO [53].

Taken together, the wide array of bone processes that NO is involved in suggest that delivery of NO to bone in a controlled and targeted manner may result in new and effective treatments for fracture repair and conditions caused by imbalances in bone turnover. The effects of exogenous NO on bone cells are thus described below.

\subsection{Effects of exogenous NO on bone cells}

3.2.1. Effects of NO on osteoblasts-Endothelial NOS generated by osteoblasts contributes to their proliferation. It is unsurprising then, that NO supplied exogenously also stimulates osteoblast growth. Osteoblast-like cells treated with the non-selective NOS inhibitor, $\mathrm{N}^{\mathrm{G}}$-monomethyl-L-arginine (L-NMMA), demonstrated a dose-dependent growth inhibition that was restored upon treatment with SNP or L-arginine [54]. Using targeted disruption of the eNOS isoform as opposed to a non-selective inhibitor demonstrated similar results; mice lacking eNOS showed reduced bone formation and bone volume [37]. Osteoblasts isolated from the femurs of eNOS deficient mice exhibited decreased proliferation and differentiation as evidenced by reduced alkaline phosphatase activity [37]. When incubated with SNAP $(1 \mu \mathrm{M})$, cell number and alkaline phosphate activity were restored to wild-type levels. To determine whether exogenous NO enhanced bone growth rather than simply restoring it following gene disruption, the same experiment was 
performed on osteoblasts from wild-type mice. Although alkaline phosphatase levels did not increase, the wild-type osteoblasts grew to increasing numbers when incubated with $1 \mu \mathrm{M}$ SNAP [37], demonstrating NO's potential as a therapeutic for bone growth.

Similarly, Otsuka et al. found that incubation of osteoblasts with an unspecified concentration of DETA/NO had no effect on alkaline phosphatase activity [54]. However, a 3.5-fold increase in osteocalcin, an osteoblast-generated protein that contributes to bone matrix mineralization was noted over the $12 \mathrm{~d}$ incubation period. Consistent with this observation was an increase in the number of mineralized bone nodules formed from osteoblasts treated with DETA/NO.

Ultimately, the rate at which NO is released from an NO donor species will significantly impact the concentration of NO in its localized sphere of influence. Since NO concentration has a profound effect on cellular activity, the release kinetics (illustrated in Figure 3) from the NO donor must be considered. Mancini et al. postulated that the slow release of NO from DETA/NO mimicked the release of NO from eNOS, while release from iNOS was more accurately modeled by a compound such as SNP that releases NO more rapidly [55]. Cell counts increased when osteoblasts were incubated with $10 \mu \mathrm{M}$ DETA/NO for $3 \mathrm{~d}$ while they were unaffected at the same concentration of SNP. At elevated NO donor concentrations $(50 \mu \mathrm{M})$, DETA/NO still contributed to cell growth while SNP initiated apoptosis. Larger NO donor concentrations $(100 \mu \mathrm{M})$ reversed the observed proliferative effect, while the trend of SNP-induced killing continued. In addition, alkaline phosphatase levels increased for cells incubated for $48 \mathrm{~h}$ in $10 \mu \mathrm{M}$ of DETA/NO but not SNP [55]. Collectively, this data suggests that the slow release of NO at low concentrations is ideal for stimulating the proliferation of osteoblasts.

Rapid release of NO only applied intermittently may also be beneficial. Buttery et al. studied osteocalcin and Cbfa-1/Runx-2 gene expression from osteoblasts supplemented with a rapid photolabile NO donor, NPR[38]. Osteoblasts derived from both wild-type and eNOS deficient mice were incubated in $5 \mu \mathrm{M}$ NPR before UV-light exposure over a period of $1 \mathrm{~s}$ to initiate NO release. This was repeated at each stage of osteoblast growth (i.e., proliferation, matrix formation, and matrix mineralization). In eNOS deficient mice, gene expression was restored to wild-type levels when treated with the NO donor. For wild-type cells exposed to NO, an increase in Cbfa-1/Runx-2 and osteocalcin expression was observed at each stage of osteoblast growth [38].

Mechanistically, the enhancement of osteoblast differentiation appears to be dependent on cGMP [55]. Formed from the activation of soluble guanylate cyclase by NO, cGMP is responsible for many of NO's biological effects [56, 57]. In the context of bone formation and repair, cGMP has been shown to enhance alkaline phosphatase and osteocalcin concentrations [58]. This upregulation is indicative of osteoblast differentiation and mineralization [59]. The pro-osteogenic cytokine IL-6 is also upregulated by cGMP, providing an explanation for the proliferative effect of $\mathrm{NO}$ on osteoblast cells [60]. However, a cGMP-dependent reduction in alkaline phosphatase is observed at high concentrations of NO making NO's effects on osteoblasts biphasic [55]. While not entirely understood, such behavior may be due to the build-up of reactive oxygen species along with a decline in the cell's mitochondrial membrane potential, ultimately initiating apoptosis [61].

3.2.2. Effects of NO on osteoclasts-Treatment of osteoclasts with exogenous NO sources causes a variety of effects dependent on NO donor concentration, NO release duration, and growth conditions. Elevated levels of NO have been shown to cause apoptosis in osteoclasts. Interestingly, cytokines like interleukin-1 (IL-1) and tumor necrosis factor (TNF) are known to enhance bone resorption despite the fact that cytokines also elicit the 
upregulation of iNOS $[40,62]$. Osteoclasts grown in mouse calvarial organ cultures were suppressed by interferon gamma, an inducer of iNOS, but only in the presence of IL-1 or TNF. Similarly, bone resorption resulting from IL-1 was suppressed when cell cultures were exposed to high concentrations of SNAP $(500 \mu \mathrm{M})$, but potentiated at low SNAP concentrations $(0.1-100 \mu \mathrm{M})$ [40], indicating that cytokine-induced bone resorption is modulated by NO. Consistent with this data, Lee et al. found that TNF upregulates iNOS and subsequently contributes to TNF-induced osteoclast survival [63]. Mice deficient in iNOS suffer abnormalities in IL-1 induced bone resorption. Supplementing osteoclasts with SNAP reversed this inhibition, but only in the presence of IL-1 which the authors attributed to an NO-dependent enhancement of resorptive pathways signaled by IL-1 [63].

One way that NO may contribute to osteoclastogenesis inhibition is through the production of osteoprotegerin (OPG). By binding RANKL, OPG halts osteoclast growth and inhibits bone resorption. When supplemented with $15 \mu \mathrm{M}$ DETA/NO, bone stromal cells from ovariectomized rats increased OPG production, resulting in inhibition of osteoclastogenesis [64]. While supplementation of murine osteoclasts with greater levels of DETA/NO (300 $\mu \mathrm{M}$ ) induced apoptosis, increasing IL-1 or RANKL concentrations in the culture medium decreased apoptosis [64]. Of note, RANKL itself is auto-regulated through NO production. Osteoclastogenesis stimulated by RANKL is controlled by a negative feedback signal, whereby RANKL upregulates interferon- $\beta$, triggering iNOS-generated $\mathrm{NO}$ and inhibiting bone resorption [65]. These studies suggest that the concentrations of cytokines and other growth factors must be considered along with NO dose and release rate. This potential synergy may be of special importance in inflammatory conditions, where cytokine concentrations are elevated [66].

The effects of exposing osteoclasts to NO also appear to be growth phase dependent. The activity of osteoclasts treated with either SNP was not affected during the proliferation phase (1-3d), but was inhibited during the differentiation phase (4-6d). Once mature, a SNP concentration of $100 \mu \mathrm{M}$ SNP was necessary to inhibit the osteoclasts [67]. Osdoby and colleagues also observed a growth phase-dependence, with NO donors capable of sustained release (e.g., SNAP) being more effective at inhibiting osteoclastogenesis than donors that release NO more transiently (e.g., PAPA/NO). This behavior may be attributed to sustained NO release occurring into the early prefusion development period when the NO donors were incubated with osteoclast-like cells [39]. This hypothesis is consistent with a report by Holliday et. al. describing activation of cGMP at low concentrations of exogenously supplied NO ( $0.1 \mu \mathrm{M}$ SNP) that disrupted the formation of osteoclasts, but had little effect on the proliferation of mature osteoclasts [68]. In contrast, mature osteoclasts respond to much higher concentrations of NO donor ( $>100 \mu \mathrm{M}$ SNP) by both cGMP-independent and dependents mechanisms [68-71]. While the cGMP-independent mechanisms may rely on the reaction of $\mathrm{NO}$ with superoxide to form peroxynitrite and cause osteoclast detachment [72], the cGMP-dependent mechanism relies on the activation of protein kinase I by cGMP. The latter facilitates osteoclast motility and detachment, ultimately reducing bone mineral matrix degradation $[70,71]$.

\subsection{Systemic NO delivery}

The benefits of systemic NO delivery have been highlighted in numerous studies [73-78]. Perhaps the most widely explored systemic uses of NO as a bone therapeutic is for the treatment of osteoporosis caused by estrogen deficiency via nitroglycerin [46]. In one example, Wimalawansa et al. compared the effects of estrogen and nitroglycerin therapies on ovariectomized rats [74]. As expected, diminished bone mineral densities observed in the ovariectomized rats were reversed with estrogen therapy. As estrogen exerts some of its action by upregulating eNOS [43], the beneficial effects of estrogen on bone mineral density reversed when a NOS inhibitor such as L-NAME was administered. Treatment of 
ovariectomized rats with nitroglycerin also reversed bone loss [74, 76], highlighting the potential of $\mathrm{NO}$ as a treatment for osteoporosis while avoiding the adverse consequences associated with hormone replacement therapy. Indeed, a retrospective analysis of data in a fracture study showed that women taking nitrates had greater bone mineral densities than women who did not [73]. After correcting for other health factors, intermittent treatment with nitrates proved most effective at increasing bone mineral density versus a daily regiment as frequent administration of nitroglycerin is associated with tolerance [79]. Similarly, a decreased efficacy was observed in rats following ovariectomy as nitroglycerin treatment frequencies increased from once to three times daily [75].

Despite promise in animal models, studies evaluating the efficacy of nitroglycerin as an osteoporosis treatment in humans have returned varied results [80]. In a one-year clinical trial carried out by Wimalawansa et al., nitroglycerin was administered topically to patients following oophorectomy. The authors observed that nitroglycerin was as effective as estrogen replacement therapy in preventing bone loss [77]. Unlike estrogen therapy, however, the nitroglycerin application increased bone formation as evidenced by increased serum alkaline phosphatase and osteocalcin levels [77]. A second three-year study examined the effect of nitroglycerin administered daily to post-menopausal women. No difference was observed between control and nitroglycerin groups, although this finding was attributed to low adherence (70\%) resulting from a side effect of persistent headaches [81]. Most recently, Jamal et al. conducted a two-year clinical trial that demonstrated topical nitroglycerin therapy on post-menopausal subjects reduced bone resorption and increased bone mineral density (Figure 1) [82]. The authors concluded that adherence to a systemic $\mathrm{NO}$ administration regimen may be an effective treatment option for osteoporosis.

\subsection{Targeted NO delivery}

A promising strategy for delivering NO to bone utilizes bisphosphonates, a class of drugs that target bone with their propensity to chelate calcium ions [83-89]. Once nitrogencontaining bisphosphonates accumulate in bone tissue, they are taken up by osteoclasts where interferences in enzyme syntheses induce apoptosis, decreasing bone resorption and ultimately contribute to a positive bone balance [3]. Due to their ability to reduce bone turnover, bisphosphonates represent an effective treatment for disorders that are characterized by excessive bone resorption such as post-menopausal osteoporosis [83]. Recently, bisphosphonates have been functionalized with organic nitrate NO donors to target NO to bone more effectively (Figure 4) [83, 90]. The nitrobisphosphonates (i.e. bisphosphonates functionalized with organic nitrates) inhibited the differentiation of RANKL-supplemented preosteoclasts (RAW 264.7 cells) into functional osteoclasts. Addition of $1 H$-[1,2,4]oxadiazole[4,3-a]quinoxalin-1-one (ODQ), a soluble guanylate cyclase inhibitor, restored differentiation, indicating that the efficacy against osteoblasts was a result of NO mediated by cGMP rather than the bisphosphonate itself. Regardless, one compound proved to be as effective as ibandronate (a clinical bisphosphonate used for the treatment of osteoporosis) at inhibiting osteoclast formation. The effect of NO-releasing bisphosphonates on mature osteoclasts was also examined, with the nitrobisphosphonates reducing the overall number of osteoclasts without affecting their activity [83]. The ability of the compounds to be taken up selectively into bone tissue (over blood and muscle) was studied using a radioactive labeling technique [83]. Bisphosphonates containing furoxans, an additional NO donor classes, were also examined for their ability to inhibit osteoclastogenesis [90]. Nitric oxide release from these compounds was demonstrated by their ability to relax rat aorta strips. This vasorelaxation was easily reversed with the addition of ODQ. Unlike nitrobisphosphonates, the anti-osteoclastogenic effects of the furoxans were not NO dependent as evidenced by the similar activity of the structurally similar furazan analogues (which are incapable of NO release). Greater doses of the 
furoxan-functionalized bisphosphonates were required to inhibit pre-osteoclast differentiation as effectively as the nitrobisphosphonates, presumably due to their alternate pharmacological mechanism.

\subsection{Localized NO delivery}

Delivery of NO to bone using macromolecular NO release scaffolds has been shown to positively affect bone tissue by aiding in fracture and bone healing [47, 91], and lowering the incidence of infection in external fixation pins [92]. To demonstrate the efficacy of local NO delivery on fracture healing, Diwan and colleagues surgically implanted an NOreleasing chitosan derivative (CBC-NONOate) at a femoral fracture site [47]. Chitosan, a biomaterial that has been used extensively in tissue engineering and drug-delivery [93-95], is functionalized with amine moieties thereby allowing for straightforward NO storage (via diazeniumdiolate formation) and NO release. After surgically inducing the fracture, $200 \mathrm{mg}$ of chitosan or CBC-NONOate was implanted into the adjacent bone tissue. The CBCNONOate was capable of delivering $10 \mu \mathrm{mol}$ of $\mathrm{NO}$ to the fracture site over $3 \mathrm{~h}$. After $17 \mathrm{~d}$, the fracture was assessed with the cross-sectional area of the associated fracture callus roughly $20 \%$ larger than with CBC alone [47].

Nitric oxide release was also shown to benefit the healing of bone defects [91]. In one study, femoral defects created in adult rats were grafted with a demineralized bone matrix solution supplemented with $S$-nitrosobovine serum albumin (SNO-BSA), an analogue of bovine serum albumin that stores NO through nitrosation of cysteine residues [91]. Approximately $150 \mathrm{nmol}$ of SNO-BSA was delivered to the defect site with equimolar NO release over 10 d. Following a 10 week post-operative period, analysis of the bone tissue showed increased union across the bone defects in the SNO-BSA group with $62 \%$ of the defects exhibiting union compared to no measureable union in the control group. Enhancements in bone mineral density and cortex modeling were also observed for the SNO-BSA group [91].

Utilizing the antimicrobial properties of $\mathrm{NO}$ to prevent post-operative infections represents an additional means by which NO may improve clinical treatments of bone. External fracture fixation pins that become infected often result in failed fracture healing and osteomyelitis [96]. Microbial biofilms may eventually form on the pin, causing recurring infections that are difficult to treat and necessitate surgery. Nitric oxide has been reported to be effective against microbial adhesion [17, 66, 97-101]. To examine whether NO release would reduce the incidence of infection for external fixation pins, Holt et al. functionalized titanium external fixation pins with diazeniumdiolate $\mathrm{NO}$ donor-functionalized xerogels (Figure 5) [92]. The NO-releasing pins were implanted into the tail vertebrae of rats and lowered the incidence of infection compared to controls. Furthermore, the surgical wounds created by the NO-releasing pin implants showed decreased incidence of edema and erythema [92]. Combined, these results may be promising for other areas of bone repair, as infection elicits an inflammatory response that may be harmful to bone tissue [102]. This study also serves as a reminder that bone tissue does not exist in vacuous isolation; fractures and surgeries also impact tendons and connective tissues in skin. As NO also regulates cellular processes in these tissues, we proceed by detailing the role of NO in wound healing and tendon healing.

\section{Nitric oxide in wound healing}

Skin, partially composed of connective tissues such as collagen, is the largest organ in the human body. Wounds occur frequently, with subsequent repair and healing of the skin taking longer as wound size increases. Upon infliction of a wound, the body responds with a blood clotting cascade and the infiltration of inflammatory cells [103, 104]. Such action is initiated by platelet accumulation at the wound site and the release of wound healing 
mediators (e.g., platelet derived growth factor), attracting macrophages and fibroblasts to assist in the deposition of granulation tissue and collagen [105]. The final deposition of collagen is essential, as this protein accounts for $>70 \%$ of the dry weight of skin with the tensile strength of the closed wound derived from the organized collagen deposition [103, $106,107]$. Several reports describing NO's involvement in reducing platelet adhesion and aggregation exist, [108-110] suggesting perhaps that NO may negatively impact acute wound healing, although this may be concentration dependent. Nevertheless, NO may prove more useful in later stages of wound healing due to the vital role NO plays in influencing angiogenesis and collagen deposition during the wound-healing cascade [111-113].

While normal fibroblasts do not synthesize NO [114], fibroblasts isolated from wounds have been shown to release NO. Furthermore, decreased collagen synthesis from the cells has been reported when NO production in wound fibroblasts was inhibited in vitro by NOS inhibition [114]. Wound fibroblasts from iNOS knockout mice also showed diminished collagen deposition with restoration of normal collagen deposition occurring upon exposure to the NO donor SNAP, indicating a direct connection between NO release and collagen production [115]. The addition of exogenous NO may also be beneficial in cells with functioning NOS isoforms as evidenced by enhanced collagen production in normal dermal fibroblasts exposed to SNAP [116, 117].

A number of studies have examined the effect of reducing NO production in wounds through chemical inhibition or targeted gene disruption of NOS to determine NO's role in wound healing [118-123]. Schaffer and coworkers inhibited wound NO synthesis by intravenous administration of the NOS inhibitors aminoguanidine and $S$-methyl isothioronium [118]. Treatment with each of the NOS inhibitors resulted in diminished hydroxyproline content in the wounded area, indicative of decreased collagen production [118]. In eNOS knockout mice, wounds required more time to fully close and once closed the wounds had a lower tensile strength compared to wild-type mice [120]. Likewise, Yamasaki et al. found that iNOS knockout mice exhibited less wound healing ability [123]. These studies show a clear relationship between healing and normal production of NO by NOS.

Systemic elevation of NO concentrations using exogenous NO donors has been explored as a strategy to modulate wound healing. Dietary supplements of arginine, a precursor to NO generation, has been reported to enhance wound healing in normal but not iNOS knockout rats, suggesting that supplemental NO enhances healing [119]. The oral administration of nitronaproxen, an organic nitrate-modified nonsteroidal anti-inflammatory drug (NSAID), showed large increases (62\%) in wound collagen deposition compared to controls [124]. Rather than enhancing systemic levels, Thornton et al. employed simple transfection of the iNOS gene to wound sites and noted increased collagen production suggesting locally applied exogenous NO may enhance wound healing [125]. While the exact mechanism by which NO enhances wound healing remains uncertain, both in vitro and in vivo wound healing studies indicate that NO promotes collagen synthesis, greatly facilitating the healing rate and ensuing tissue strength.

\subsection{Topical application of nitric oxide in vivo}

Given that NO increases collagen deposition at wound sites, it is not surprising that topical application of NO has also been shown to enhance wound healing. Shekhter et al. simply exposed the wounds of normal and infected rats to daily doses of NO (500 ppm for $60 \mathrm{~s})$ [126]. Rats treated with NO experienced an increased rate of wound closure in both aseptic and infected conditions [126]. After $10 \mathrm{~d}$ of NO exposure, the area of the NO-treated aseptic wounds was almost 50\% smaller than those left untreated [126]. Furthermore, infected wounds treated with NO healed quicker with a $\sim 50 \%$ decrease in wound area after $21 \mathrm{~d}$ 
[126]. Faster healing has been attributed to the anti-microbial properties of $\mathrm{NO}$ and the killing of bacteria in the wound site [17, 66, 97-101, 127]. While clearly beneficial, such NO delivery raises toxicity concerns and is impractical from an expense and safety standpoint (e.g., high pressure gas cylinders, expensive equipment).

As an alternative to gaseous NO, the use of NO donors would simplify the delivery of NO to wound sites. In an early study performed by Shabani and coworkers, $N$-diazeniumdiolated polyethyleneimine cellulose (PEIC-NO) applied to open rat wounds was found to promote more rapid wound closure compared to control treatments [128]. Likewise, Amadeu et al. found that application of a hydrogel containing $S$-nitrosoglutathione $(100 \mu \mathrm{M})$ to a rat wound enhanced healing, wound closing time, mast cell infiltration, and resulted in more organized and mature collagen deposition [129]. In further studies with the $S$ nitrosoglutathione containing-hydrogel, Amadeu et al. concluded that delivery of exogenous NO during both the inflammatory and proliferative stages enhanced healing more than if NO was applied during only one stage or the other [130].

4.1.1 Burn wounds-In contrast to chronic wounds that may heal, patients with serious burn wounds often never achieve complete recovery without treatment [131]. Indeed, burn wounds are of particular importance as they are common, difficult to treat and often lead to infection; severe burn wounds occur annually at a rate of 5 per 100,000 people [131].

Several groups have investigated NO's role in burn healing and recovery time. Although indirect, increased nitrate levels in urine were observed following the infliction of a burn wound in a rat until the wound completely healed $[132,133]$. In related research, Paulsen et al. found that iNOS levels were significantly increased in burned skin [134]. Likewise, the inhibition of eNOS and iNOS using L-NAME or aminoguanidine was reported to both delay the healing of thermal wounds and depress vascular hyperpermeability $[135,136]$.

A major aim in burn wound research is to increase the rate and completeness of healing [137]. To determine if exogenously administrated NO may fulfill these criteria, Zhu and coworkers applied $\mathrm{NO}$ topically to rat burn wounds using a sodium nitrite gel $(14.6 \mathrm{mM})$ at reduced $\mathrm{pH}[138,139]$. Treatment with the NO-releasing gel resulted in quicker wound closure and increased angiogenesis in addition to an enhanced rate of collagen deposition as measured by the number of procollagen-positive fibroblasts in the wound over time [138, 139]. Also observed was that topical application of NO to one burn wound did not affect the healing of other burn wounds on the same animal, proving it necessary to deliver NO locally and directly to the wound area of interest [139].

4.1.2 Diabetic wounds-Due to NO's role as a healing and antibacterial agent, NO release may also prove useful as a treatment for diabetic foot ulcers (DFUs). Wound healing is problematic for diabetics where delayed/diminished healing capability (i.e., collagen deposition and wound breaking strength) and infection, possibly due to a lack of NO in such wounds, result in chronic wounds that do not close [140,141]. Even when glucose levels are controlled by insulin, diabetic models exhibit diminished nitrate/nitrite levels and collagen deposition during wound healing compared to non-diabetic animals [140, 142]. To assess the impact of exogenous $\mathrm{NO}$ on wound closure, diabetic rats were fed molsidomine, a vasodilating drug that is metabolized in the liver to morpholino-sydnonimine (SIN-1) [142144]. SIN-1 is a reactive metabolite that releases NO (Figure 7) [144]. The wounds of molsidomine-fed rats exhibited increased breaking strength and hydroxyproline levels after $10 \mathrm{~d}$ of treatment, both indicative of enhanced collagen deposition [142, 143].

While increased NO levels have been shown to enhance wound healing, the localized delivery of NO at the wound site has only recently been achieved using topical NO donor application. For example, Weller et al. compared wound healing in normal and diabetic mice 
using a topical treatment of acidified nitrite. Applying the treatment as an aqueous cream containing 3 and $4.5 \%$ (w/v) of sodium nitrite and citric acid, respectively, improved healing, as quantified by wound area, in both normal and diabetic mice [145]. Although NO improved wound healing in non-diabetic animals, the rate of healing observed in the diabetic mice was significantly greater, likely due to the NO deficiencies present in the diabetic animals [145]. Unfortunately, the topical administration of nitrites may have unfavorable pro-inflammatory effects, making other NO delivery methods more desirable and beneficial to wound healing [146].

Concerns about acidified nitrites may be abrogated using NO donors that spontaneously release NO (e.g. $\mathrm{N}$-diazeniumdiolates). Dashti and coworkers measured collagen production of NO-treated and untreated wounds in a diabetic rat model by implanting polyvinyl alcohol sponges and administering $100 \mu \mathrm{M}$ DETA/NO in phosphate buffered saline at $3 \mathrm{~d}$ intervals [147]. After 6 days, the sponges were explanted and protein analysis of the wound fluid revealed enhanced collagen production for the NO-treated wounds [147]. Li and colleagues covered wounds with a poly(vinyl methyl ether-co-maleic anhydride) (PVMMA) and poly(vinyl pyrrolidone) (PVP) hybrid polymer modified with $S$-nitrosothiolglutathione or phytochelatin residues to diabetic rat wounds [148]. These nitrosated polymers released approximately $50 \mathrm{nmol} \mathrm{NO}$ per mg of nanoparticles over $12 \mathrm{~d}$ at $37^{\circ} \mathrm{C}$ in ambient light [148]. As such, $\mu \mathrm{mol}$ levels of NO were released into the wound bed subsequently accelerating wound closure at 4, 7 and $10 \mathrm{~d}$ post-wound infliction as determined by a decrease in wound area [148]. Despite these initial feasibility studies, much remains unknown regarding the ideal NO release kinetics and amounts required to facilitate wound healing.

Of note, the increased rate of infection in diabetic wounds make individuals with diabetes a high-risk group for orthopedic infections [149]. By utilizing an NO-releasing orthopedic implant similar to that discussed in section 3.5, complications associated with orthopedic device infections in both diabetic and non-diabetic rats should be assessed. Overcoming bacterial colonization in bone and the surrounding tissue through the release of NO may reduce the rate of implant-associated infections, ultimately reducing failure rates and increasing the quality of orthopedic care for diabetic patients.

\section{Nitric oxide in tendon healing}

Tendons are an integral part of the mammalian musculoskeletal system and act to transfer force created by muscles to movement of bones [150]. Collagen is a major component of these connective tissues, accounting for $>70 \%$ of the tendon dry weight [150]. Injuries to tendons due to overuse, termed tendinopathy, currently have limited treatment options [151]. Nitric oxide's role in tendon repair is based on the ability to promote collagen deposition and strengthen this tissue. Several studies have shown that reduced NO production inhibits tendon healing and collagen synthesis $[152,153]$. Nitric oxide release from fibroblasts promotes collagen synthesis, further highlighting the potential of NO-releasing therapies in tendon repair [114, 117, 152]. For example, Murrell and coworkers reported that cultured tendon cells treated with SNAP altered their collagen synthesis in a dose dependent manner $[154,155]$. Low concentrations of SNAP $(<100 \mu \mathrm{M})$ had no effect on collagen synthesis. In contrast, much larger SNAP concentrations $(800 \mu \mathrm{M})$ impeded collagen synthesis [155]. Intermediate concentrations of SNAP $(100$ and $400 \mu \mathrm{M})$ significantly promoted collagen synthesis, emphasizing the importance of NO donor dose [155]. The mRNA expression from cultured tenocytes for a number of proteins indicated that the most optimal healing may be achieved by varying the dose of NO from a high initial concentration to a low concentration over time [154]. Collectively, these studies highlight the potential of NO to 
treat tendon injury and show the need to control localized $\mathrm{NO}$ concentrations to promote and not inhibit collagen deposition [154, 156].

\subsection{Delivery of nitric oxide to tendons in vivo}

A number of pre-clinical studies support the utility of exogenous NO to promote tendon healing. Lin et al. reported a time-dependent upregulation of the three NOS isoforms (eNOS, iNOS and nNOS) after wounding of the Achilles tendons in rats [157, 158]. Inhibition of the NOS proteins during the healing of ruptured Achilles tendons in rats resulted in a reduced cross-sectional area of the healing tendon [156]. Yuan et al. found that daily and localized injection of NO-generating nitroflurbiprofen improved collagen organization and tendon stress in rats with injured Achilles tendons $10 \mathrm{~d}$ post-injury relative to controls [159]. Similarly, the effect of injecting nitroparacetamol ( $48 \mathrm{mg} \mathrm{kg}^{-1}$ per day) at wounded Achilles tendons in rats had no significant effect on the failure load of the tendons, but the treatment increased both collagen organization and content [160].

Investigation of tendon healing in human patients has focused on topical administration of NO donors, a treatment that is much simpler and less likely to disrupt surrounding tissue. FDA-approved nitroglycerin patches have been tested on human patients and proven useful due to their analgesic effects for painful tendon injuries [161]. In addition to pain reduction, the nitroglycerin patches improved the likelihood of complete healing after six months of treatment [162-164]. A three-year follow-up study of nitroglycerin patch treatment of chronic noninsertional Achilles tendinopathy reported that patients who used the NOproducing patches for six months were more asymptomatic than those receiving placebos, providing evidence of the benefits of $\mathrm{NO}$ on long-term healing of tendons [165]. Though these results appear promising, other studies have found no differences between NO treatment and control groups in similar short-term studies and long-term follow-ups [166168]. For example, an eight-week study by Paolini et al. examined the dose-dependence of topical nitroglycerin for the treatment of chronic lateral epicondylosis, but the only observed effect was a reduction in elbow pain for one dosage of nitroglycerin [168]. Of note, treatments that were previously successful were based on the use of nitroglycerin patches and a longer treatment period in conjunction with physical therapy $[162,168]$. While the use of nitroglycerin patches is convenient due to their FDA status, it would be useful to test other NO donors as nitroglycerin has adverse side effects (e.g., headaches) that cause noncompliance [162-164]. Furthermore, prolonged use of organic nitrates may lead to tolerance, diminishing treatment benefits. Further studies must determine the role of NO administration and amount of NO release on tendon healing. Clearly, the importance of physical therapy on tendon healing with and in the absence of NO should be ascertained. Additionally, the amount of actual NO delivery must be more carefully reported since NOdonor concentrations alone rarely correlate with $\mathrm{NO}$ release kinetics and lifetimes across NO-donor chemical structures.

\section{Conclusion and outlook}

To limit complex signaling cascades that may convolute data and provide undesirable side effects during treatment, localizing delivery of $\mathrm{NO}$ has proven essential for a number of biological applications, especially considering its short half-life and limited sphere of influence. Thus far, the primary strategies utilized for treatment of bones with NO involve systemic transdermal uptake of organic nitrates or implantation of $\mathrm{NO}$ donors at the site of injury. A number of examples have also appeared describing localized NO release from the surfaces of bone plates and screws in vivo (e.g., NO-releasing xerogels), though the use of an implantable material limits treatment to applications requiring surgery. Surgical procedures may be avoided with the use of targeted NO release achieved with NO-releasing 
bisphosphonates. Additional studies utilizing such NO donors in vivo will contribute needed evidence for their efficacy in bone healing.

Wound healing models have implemented a wide range of NO donor types and concentrations. The advantages of NO release in wound healing have been shown in several instances, but little work has focused on the topical treatment of burns or diabetic wounds. These two types of wounds represent slow-healing chronic challenges that may benefit greatly from NO's accelerated healing attributes. To date, most research in these areas has utilized NO-releasing nanoparticles or potentially pro-inflammatory sources of NO (e.g., nitrite gels) that ultimately may negatively impact the overall tissue response. Future studies should carefully consider the NO donor used, specifically elucidating the role that NOrelease kinetics may have on wound healing.

Examples of applying NO donors to tendons have exclusively focused on the use of organic nitrates. These molecules provide some advantages, but the potential of forming tolerance and undesirable side effects may preclude their clinical utility. The need to assess the efficacy of other NO donor molecules that may circumvent the problems of organic nitrates while maintaining suitable biocompatibility is great. Such NO donors would likely be administered by direct injection or via a transdermal patch to maximize delivery of NO to the injury site. Furthermore, a connection between NO delivery and physical therapy should be explored as it may prove to be an important factor in the efficacy of NO treatment for tendon injuries.

In closing, a number of questions remain regarding the optimal dose of NO necessary to modulate the repair of bone, skin, and tendon tissues. Most in vivo studies to date have employed organic nitrates, an inherently challenging NO donor to work with due to a nonspontaneous NO release mechanism, as well as undesirable side effects and evolving tolerance. Studies utilizing NO donors that release NO by more spontaneous mechanisms (e.g., $N$-diazeniumdiolates and $S$-nitrosothiols) should be more carefully considered to better evaluate controlled, localized delivery of $\mathrm{NO}$ as a therapy. Appropriate testing of such donors should be undertaken both in vitro and in vivo to ascertain the role of NO-release kinetics and NO flux on bone, skin, and tendon healing. The most promising materials should then be evaluated clinically.

\section{Acknowledgments}

This research was supported by the National Institutes of Health (EB000708)

\section{Abbreviations}

\section{CBC-NONOate \\ cGMP \\ DETA/NO}

DFU

eNOS

GSNO

iNOS

L-NAME
$\mathrm{N}$-diazeniumdiolate-functionalized chitosan

cyclic guanosine monophosphate

1- $N$-(aminoethyl)- $N$-(2-ammonioethyl)amino] diazen-1-ium-1,2diolate

diabetic foot ulcer

endothelial nitric oxide synthase

$S$-nitrosoglutathione

inducible nitric oxide synthase

$\mathrm{L}-N^{\mathrm{G}}$-nitroarginine methyl ester 


$\begin{array}{ll}\text { L-NMMA } & \mathrm{N}^{\mathrm{G}} \text {-monomethyl-L-arginine } \\ \text { mTALH } & \text { mitochondrial aldehyde dehydrogenase } \\ \text { NO } & \text { nitric oxide } \\ \text { nNOS } & \text { neuronal nitric oxide synthase } \\ \text { NOS } & \text { nitric oxide synthase } \\ \text { NPR } & \text { potassium nitrosylpentachlororuthenate } \\ \text { NSAID } & \text { nonsteroidal anti-inflammatory drug } \\ \text { ODQ } & 1 H \text {-[1,2,4]oxadiazole[4,3-a]quinoxalin-1-one } \\ \text { OPG } & \text { osteoprotegerin } \\ \text { PAPA/NO } & \text { (Z)-1-[ } N \text {-(3-aminopropyl)- } N \text {-(n-propyl)amino]diazen-1-ium-1,2- } \\ \text { PEIC-NO } & \text { diolate } \\ \text { PVMMA } & N \text {-diazeniumdiolated polyethyleneimine cellulose } \\ \text { PVP } & \text { poly(vinyl methyl ether-comaleic anhydride) } \\ \text { RANKL } & \text { poly(vinyl pyrrolidone) } \\ \text { SIN-1 } & \text { receptor activator of nuclear factor kappa-B ligand } \\ \text { SNAP } & \text { morpholino-sydnonimine } \\ \text { SNO-BSA } & S \text {-nitroso- } N \text {-acetyl-penicillamine } \\ \text { SNP } & S \text {-nitrosobovine serum albumin } \\ \text { IL-1 } & \text { sodium nitroprusside } \\ \text { TNF } & \text { tumor necrosis factor } \\ & \end{array}$

\section{References}

[1]. Hetrick EM, Schoenfisch MH. Reducing implant-related infections: active release strategies. Chem. Soc. Rev. 2006; 35:780-789. [PubMed: 16936926]

[2]. Simchi A, Tamjid E, Pishbin F, Boccaccini AR. Recent progress in inorganic and composite coatings with bactericidal capability for orthopaedic applications. Nanomed. Nanotechnol. Biol. Med. 2011; 7:22-39.

[3]. Rodan GA, Martin TJ. Therapeutic Approaches to Bone Diseases. Science. 2000; 289:1508-1514. [PubMed: 10968781]

[4]. Bilezikian, JP.; Raisz, LG.; Rodan, GA. Principles of bone biology. Academic Press; San Diego: 1996.

[5]. Dimitriou R, Tsiridis E, Giannoudis PV. Current concepts of molecular aspects of bone healing. Injury. 2005; 36:1392-1404. [PubMed: 16102764]

[6]. Laurencin CT, Ambrosio AMA, Borden MD, Cooper JA. Tissue Engineering: Orthopedic Applications. Annu. Rev. Biomed. Eng. 1999; 1:19-46. [PubMed: 11701481]

[7]. Ignarro, LJ. Nitric oxide: biology and pathobiology. Academic; San Diego, Calif.: London: 2000.

[8]. Williams DLH. A chemist's view of the nitric oxide story. Org. Biomol. Chem. 2003; 1:441-449. [PubMed: 12926240]

[9]. Griffith OW, Stuehr DJ. Nitric Oxide Synthases: Properties and Catalytic Mechanism. Annu. Rev. Physiol. 1995; 57:707-734. [PubMed: 7539994] 
[10]. Malinski T, Taha Z, Grunfeld S, Patton S, Kapturczak M, Tomboulian P. Diffusion of Nitric Oxide in the Aorta Wall Monitored in Situ by Porphyrinic Microsensors. Biochem. Biophys. Res. Commun. 1993; 193:1076-1082. [PubMed: 8323533]

[11]. Nablo BJ, Prichard HL, Butler RD, Klitzman B, Schoenfisch MH. Inhibition of implantassociated infections via nitric oxide release. Biomaterials. 2005; 26:6984-6990. [PubMed: 15978663]

[12]. Hrabie JA, Keefer LK. Chemistry of the nitric oxide-releasing diazeniumdiolate ("nitrosohydroxylamine") functional group and its oxygen-substituted derivatives. Chem. Rev. 2002; 102:1135-1154. [PubMed: 11942789]

13. Davies KM, Wink DA, Saavedra JE, Keefer LK. Chemistry of the diazeniumdiolates. 2. Kinetics and mechanism of dissociation to nitric oxide in aqueous solution. J. Am. Chem. Soc. 2001; 123:5473-5481. [PubMed: 11389629]

[14]. Williams DLH. The chemistry of S-nitrosothiols. Accounts Chem. Res. 1999; 32:869-876.

[15]. Seabra AB, Duran N. Nitric oxide-releasing vehicles for biomedical applications. J. Mater. Chem. 2010; 20:1624-1637.

[16]. Keefer LK, Nims RW, Davies KM, Wink DA. "NONOates" (1-substituted diazen-1-ium-1,2diolates) as nitric oxide donors: Convenient nitric oxide dosage forms. Methods Enzymol. 1996; 268:281-293. [PubMed: 8782594]

[17]. Riccio DA, Dobmeier KP, Hetrick EM, Privett BJ, Paul HS, Schoenfisch MH. Nitric oxidereleasing S-nitrosothiol-modified xerogels. Biomaterials. 2009; 30:4494-4502. [PubMed: 19501904]

[18]. Shin JH, Metzger SK, Schoenfisch MH. Synthesis of nitric oxide-releasing silica nanoparticles. J. Am. Chem. Soc. 2007; 129:4612-4619. [PubMed: 17375919]

[19]. Shin JH, Schoenfisch MH. Inorganic/Organic Hybrid Silica Nanoparticles as a Nitric Oxide Delivery Scaffold. Chem. Mater. 2008; 20:239-249.

[20]. Riccio DA, Nugent JL, Schoenfisch MH. Stober Synthesis of Nitric Oxide-Releasing SNitrosothiol-Modified Silica Particles. Chem. Mater. 2011; 23:1727-1735. [PubMed: 21499510]

[21]. Stasko NA, Schoenfisch MH. Dendrimers as a scaffold for nitric oxide release. J. Am. Chem. Soc. 2006; 128:8265-8271. [PubMed: 16787091]

[22]. Stasko NA, Fischer TH, Schoenfisch MH. S-nitrosothiol-modified dendrimers as nitric oxide delivery vehicles. Biomacromolecules. 2008; 9:834-841. [PubMed: 18247567]

[23]. Mowery KA, Schoenfisch MH, Saavedra JE, Keefer LK, Meyerhoff ME. Preparation and characterization of hydrophobic polymeric films that are thromboresistant via nitric oxide release. Biomaterials. 2000; 21:9-21. [PubMed: 10619674]

[24]. Parzuchowski PG, Frost MC, Meyerhoff ME. Synthesis and Characterization of Polymethacrylate-Based Nitric Oxide Donors. J. Am. Chem. Soc. 2002; 124:12182-12191. [PubMed: 12371858]

[25]. Coneski PN, Rao KS, Schoenfisch MH. Degradable Nitric Oxide-Releasing Biomaterials via Post-Polymerization Functionalization of Cross-Linked Polyesters. Biomacromolecules. 2010; 11:3208-3215.

[26]. Coneski PN, Nash JA, Schoenfisch MH. Nitric Oxide-Releasing Electrospun Polymer Microfibers. ACS Appl. Mater. Interfaces. 2011; 3:426-432. [PubMed: 21250642]

[27]. Wang PG, Xian M, Tang X, Wu X, Wen Z, Cai T, Janczuk AJ. Nitric Oxide Donors: Chemical Activities and Biological Applications. Chem. Rev. 2002; 102:1091-1134. [PubMed: 11942788]

[28]. Murad F. The excitement and rewards of research with our discovery of some of the biological effects of nitric oxide. Circ. Res. 2003; 92:339-341. [PubMed: 12623869]

[29]. Chen Z, Zhang J, Stamler JS. Identification of the enzymatic mechanism of nitroglycerin bioactivation. PNAS. 2002; 99:8306-8311. [PubMed: 12048254]

[30]. Chen Z, Foster MW, Zhang J, Mao L, Rockman HA, Kawamoto T, Kitagawa K, Nakayama KI, Hess DT, Stamler JS. An essential role for mitochondrial aldehyde dehydrogenase in nitroglycerin bioactivation. PNAS. 2005; 102:12159-12164. [PubMed: 16103363]

[31]. Sydow K, Daiber A, Oelze M, Chen Z, August M, Wendt M, Ullrich V, Mülsch A, Schulz E, Keaney J. John F. Stamler JS, Münzel T. Central role of mitochondrial aldehyde dehydrogenase 
and reactive oxygen species in nitroglycerin tolerance and cross-tolerance. J. Clin. Invest. 2004; 113:482-489. [PubMed: 14755345]

[32]. Daiber A, Oelze M, Coldewey M, Bachschmid M, Wenzel P, Sydow K, Wendt M, Kleschyov AL, Stalleicken D, Ullrich V, M ü lsch A, M ü nzel T. Oxidative Stress and Mitochondrial Aldehyde Dehydrogenase Activity: A Comparison of Pentaerythritol Tetranitrate with Other Organic Nitrates. Mole. Pharmacol. 2004; 66:1372-1382.

[33]. McCleverty JA. Chemistry of Nitric Oxide Relevant to Biology. Chem. Rev. 2004; 104:403-418. [PubMed: 14871130]

[34]. Yip K-P. Flash photolysis of caged nitric oxide inhibits proximal tubular fluid reabsorption in free-flow nephron. Am. J. Physiol.-Reg. I. 2005; 289:R620-R626.

[35]. Bettache N, Carter T, Corrie JET, Ogden D, Trentham DR. Photolabile donors of nitric oxide: Ruthenium nitrosyl chlorides as caged nitric oxide. Methods Enzymol. 1996; 268:266-281. [PubMed: 8782593]

[36]. Teitelbaum SL. Bone Resorption by Osteoclasts. Science. 2000; 289:1504-1508. [PubMed: 10968780]

[37]. Aguirre J, Buttery L, O'Shaughnessy M, Afzal F, Fernandez de Marticorena I.g. Hukkanen M, Huang P, MacIntyre I, Polak J. Endothelial Nitric Oxide Synthase Gene-Deficient Mice Demonstrate Marked Retardation in Postnatal Bone Formation, Reduced Bone Volume, and Defects in Osteoblast Maturation and Activity. Am. J. Pathol. 2001; 158:247-257. [PubMed: 11141498]

[38]. Afzal F, Polak J, Buttery L. Endothelial nitric oxide synthase in the control of osteoblastic mineralizing activity and bone integrity. J. Pathol. 2004; 202:503-510. [PubMed: 15095278]

[39]. Collin-Osdoby P, Rothe L, Bekker S, Anderson F, Osdoby P. Decreased Nitric Oxide Levels Stimulate Osteoclastogenesis and Bone Resorption Both in Vitro and in Vivo on the Chick Chorioallantoic Membrane in Association with Neoangiogenesis. J. Bone Miner. Res. 2000; 15:474-488. [PubMed: 10750562]

[40]. Ralston SH, Ho L-P, Helfrich MH, Grabowski PS, Johnston PW, Benjamin N. Nitric oxide: A cytokine-induced regulator of bone resorption. J. Bone Miner. Res. 1995; 10:1040-1049. [PubMed: 7484279]

[41]. Nilforoushan D, Gramoun A, Glogauer M, Manolson MF. Nitric oxide enhances osteoclastogenesis possibly by mediating cell fusion. Nitric Oxide-Biol. Chem. 2009; 21:27-36.

[42]. Hughes DE, Dai A, Tiffee JC, Li HH, Mundy GR, Boyce BF. Estrogen promotes apoptosis of murine osteoclasts mediated by TGF-[beta]. Nat. Med. 1996; 2:1132-1136. [PubMed: 8837613]

[43]. Armour KE, Ralston SH. Estrogen Upregulates Endothelial Constitutive Nitric Oxide Synthase Expression in Human Osteoblast-Like Cells. Endocrinology. 1998; 139:799-802. [PubMed: 9449657]

[44]. O'Shaughnessy MC, Polak JM, Afzal F, Hukkanen MVJ, Huang P, MacIntyre I, Buttery LDK. Nitric Oxide Mediates 17[beta]-Estradiol-Stimulated Human and Rodent Osteoblast Proliferation and Differentiation. Biochem. Biophys. Res. Commun. 2000; 277:604-610. [PubMed: 11062001]

[45]. Armour KE, Armour KJ, Gallagher ME, Godecke A, Helfrich MH, Reid DM, Ralston SH. Defective Bone Formation and Anabolic Response to Exogenous Estrogen in Mice with Targeted Disruption of Endothelial Nitric Oxide Synthase. J. Endocrinol. 2001; 142:760-766.

[46]. Wimalawansa SJ. Nitric oxide: novel therapy for osteoporosis. Expert Opin. Pharmacother. 2008; 9:3025-3044. [PubMed: 19006476]

[47]. Diwan AD, Wang MX, Jang D, Zhu W, Murrell GAC. Nitric Oxide Modulates Fracture Healing. J. Bone Miner. Res. 2000; 15:342-351. [PubMed: 10703937]

[48]. Baldik Y, Diwan AD, Appleyard RC, Ming Fang Z, Wang Y, Murrell GAC. Deletion of iNOS gene impairs mouse fracture healing. Bone. 2005; 37:32-36. [PubMed: 15894526]

[49]. Rubin J, Murphy T, Nanes MS, Fan X. Mechanical strain inhibits expression of osteoclast differentiation factor by murine stromal cells. Am. J. Physiol-Cell Ph. 2000; 278:C1126-C1132.

[50]. Rubin J, Fan X, Biskobing DM, Taylor WR, Rubin CT. Osteoclastogenesis is repressed by mechanical strain in an in vitro model. J. Orthopaed. Res. 1999; 17:639-645. 
[51]. Rangaswami H, Marathe N, Zhuang S, Chen Y, Yeh J-C, Frangos JA, Boss GR, Pilz RB. Type II cGMP-dependent Protein Kinase Mediates Osteoblast Mechanotransduction. J. Biol. Chem. 2009; 284:14796-14808. [PubMed: 19282289]

[52]. Rubin J, Murphy TC, Zhu L, Roy E, Nanes MS, Fan X. Mechanical Strain Differentially Regulates Endothelial Nitric-oxide Synthase and Receptor Activator of Nuclear KB Ligand Expression via ERK1/2 MAPK. J. Biol. Chem. 2003; 278:34018-34025. [PubMed: 12824189]

[53]. Rahnert J, Fan X, Case N, Murphy TC, Grassi F, Sen B, Rubin J. The role of nitric oxide in the mechanical repression of RANKL in bone stromal cells. Bone. 2008; 43:48-54. [PubMed: 18440890]

[54]. Otsuka E, Hirano K, Matsushita S, Inoue A, Shigehisa H, Yamaguchi A, Hagiwara H. Effects of nitric oxide from exogenous nitric oxide donors on osteoblastic metabolism. Eur. J. Pharmacol. 1998; 349:345-350. [PubMed: 9671116]

[55]. Mancini L, Moradi-Bidhendi N, Becherini L, Martineti V, MacIntyre I. The Biphasic Effects of Nitric Oxide in Primary Rat Osteoblasts Are cGMP Dependent. Biochem. Biophys. Res. Commun. 2000; 274:477-481. [PubMed: 10913363]

[56]. Radomski MW, Palmer RMJ, Moncada S. The role of nitric oxide and cGMP in platelet adhesion to vascular endothelium. Biochem. Biophys. Res. Commun. 1987; 148:1482-1489. [PubMed: 2825688]

[57]. Ignarro LJ, Harbison RG, Wood KS, Kadowitz PJ. Activation of purified soluble guanylatecyclase by endothelium-derived relaxing factor from intrapulmonary artery and vein Stimulation by acetylcholine, bradykinn and arachidonic-acid. J. Pharmacol. Exp. Ther. 1986; 237:893-900. [PubMed: 2872327]

[58]. Hagiwara H, Inoue A, Yamaguchi A, Yokose S, Furuya M, Tanaka S, Hirose S. cGMP produced in response to ANP and CNP regulates proliferation and differentiation of osteoblastic cells. Am. J. Physiol.-Cell Physiol. 1996; 270:C1311-C1318.

[59]. Otsuka E, Hirano K, Matsushita S, Inoue A, Hirose S, Yamaguchi A, Hagiwara H. Effects of nitric oxide from exogenous nitric oxide donors on osteoblastic metabolism. Eur. J. Pharmacol. 1998; 349:345-350. [PubMed: 9671116]

[60]. Broderick KE, Zhang T, Rangaswami H, Zeng Y, Zhao X, Boss GR, Pilz RB. Guanosine 3 ',5'cyclic monophosphate (cGMP)/cGMP-dependent protein kinase induce interleukin-6 transcription in osteoblasts. Mol. Endocrinol. 2007; 21:1148-1162. [PubMed: 17341596]

[61]. Chen RM, Chen TL, Chiu WT, Chang CC. Molecular mechanism of nitric oxide-induced osteoblast apoptosis. J. Orthop. Res. 2005; 23:462-468. [PubMed: 15734263]

[62]. Van 't Hof RJ, Ralston SH. Cytokine-induced nitric oxide inhibits bone resorption by inducing apoptosis of osteoclast progenitors and suppressing osteoclast activity. J. Bone Miner. Res. 1997; 12:1797-1804. [PubMed: 9383684]

[63]. Lee SK, Huang H, Lee SW, Kim KH, Kim KK, Kim H-M, Lee ZH, Kim H-H. Involvement of iNOS-dependent NO production in the stimulation of osteoclast survival by TNF-[alpha]. Exp. Cell. Res. 2004; 298:359-368. [PubMed: 15265685]

[64]. Kanaoka K, Kobayashi Y, Hashimoto F, Nakashima T, Shibata M, Kobayashi K, Kato Y, Sakai H. A Common Downstream Signaling Activity of Osteoclast Survival Factors That Prevent Nitric Oxide-Promoted Osteoclast Apoptosis. J. Endocrinol. 2000; 141:2995-3005.

[65]. Zheng H, Yu X, Collin-Osdoby P, Osdoby P. RANKL stimulates inducible nitric-oxide synthase expression and nitric oxide production in developing osteoclasts - An autocrine negative feedback mechanism triggered by RANKL-induced interferon-beta via NF-kappa B that restrains osteoclastogenesis and bone resorption. J. Biol. Chem. 2006; 281:15809-15820. [PubMed: 16613848]

[66]. Hetrick EM, Schoenfisch MH. Antibacterial nitric oxide-releasing xerogels: Cell viability and parallel plate flow cell adhesion studies. Biomaterials. 2007; 28:1948-1956. [PubMed: 17240444]

[67]. Holliday LS, Dean AD, Lin RH, Greenwald JE, Gluck SL. Low NO concentrations inhibit osteoclast formation in mouse marrow cultures by cGMP-dependent mechanism. Am. J. Physol.Renal. 1997; 272:F283-F291. 
[68]. Holliday LS, Dean AD, Lin RH, Greenwald JE, Gluck SL. Low NO concentrations inhibit osteoclast formation in mouse marrow cultures by cGMP-dependent mechanism. Am. J. Physiol.-Renal Physiol. 1997; 272:F283-F291.

[69]. MacIntyre I, Zaidi M, Alam AS, Datta HK, Moonga BS, Lidbury PS, Hecker M, Vane JR. Osteoclastic inhibition: an action of nitric oxide not mediated by cyclic GMP. PNAS. 1991; 88:2936-2940. [PubMed: 1849281]

[70]. Yaroslavskiy BB, Zhang YJ, Kalla SE, Palacios VG, Sharrow AC, Li YN, Zaidi M, Wu CY, Blair HC. NO-dependent osteoclast motility: reliance on cGMP-dependent protein kinase I and VASP. J. Cell Sci. 2005; 118:5479-5487. [PubMed: 16291726]

[71]. Yaroslavskiy BB, Li YN, Ferguson DJP, Kalla SE, Oakley JI, Blair HC. Autocrine and paracrine nitric oxide regulate attachment of human osteoclasts. J. Cell. Biochem. 2004; 91:962-972. [PubMed: 15034931]

[72]. Mancini L, Moradi-Bidhendi N, Brandi ML, MacIntyre I. Nitric oxide superoxide and peroxynitrite modulate osteoclast activity. Biochem. Biophys. Res. Commun. 1998; 243:785790. [PubMed: 9501002]

[73]. Jamal SA, Browner WS, Bauer DC, Cummings SR. Intermittent Use of Nitrates Increases Bone Mineral Density: The Study of Osteoporotic Fractures. J. Bone Miner. Res. 1998; 13:1755-1759. [PubMed: 9797485]

[74]. Wimalawansa SJ, De Marco G, Gangula P, Yallampalli C. Nitric oxide donor alleviates ovariectomy-induced bone loss. Bone. 1996; 18:301-304. [PubMed: 8726385]

[75]. Wimalawansa S, Chapa T, Fang L, Yallampalli C, Simmons D, Wimalawansa S. FrequencyDependent Effect of Nitric Oxide Donor Nitroglycerin on Bone. J. Bone Miner. Res. 2000; 15:1119-1125. [PubMed: 10841180]

[76]. Hukkanen M, Platts LAM, Lawes T, Girgis SI, Konttinen YT, Goodship AE, MacIntyre I, Polak JM. Effect of nitric oxide donor nitroglycerin on bone mineral density in a rat model of estrogen deficiency-induced osteopenia. Bone. 2003; 32:142-149. [PubMed: 12633786]

[77]. Wimalawansa SJ. Nitroglycerin Therapy Is as Efficacious as Standard Estrogen Replacement Therapy (Premarin) in Prevention of Oophorectomy-Induced Bone Loss: A Human Pilot Clinical Study. J. Bone Miner. Res. 2000; 15:2240-2244. [PubMed: 11092405]

[78]. Kdolsky R, Mohr W, Savidis-Dacho H, Beer R, Puig S, Reihsner R, Tangl S, Donath K. The influence of oral L-arginine on fracture healing: an animal study. Wien. Klin. Wochenschr. 2005; 117:693-701. [PubMed: 16416369]

[79]. Agvald P, Adding LC, Gustafsson LE, Persson MG. Nitric oxide generation, tachyphylaxis and cross-tachyphylaxis from nitrovasodilators in vivo. Eur. J. Pharmacol. 1999; 385:137-145. [PubMed: 10607869]

[80]. Khosla S. Is Nitroglycerin a Novel and Inexpensive Treatment for Osteoporosis? J. Am. Med. Ass. 2011; 305:826-827.

[81]. Wimalawansa SJ, Grimes JP, Wilson AC, Hoover DR. Transdermal Nitroglycerin Therapy May Not Prevent Early Postmenopausal Bone Loss. J. Clin. Endocr. Metab. 2009; 94:3356-3364. [PubMed: 19549739]

[82]. Jamal SA, Hamilton CJ, Eastell R, Cummings SR. Effect of Nitroglycerin Ointment on Bone Density and Strength in Postmenopausal Women. J. Am. Med. Ass. 2011; 305:800-807.

[83]. Lazzarato L, Rolando B, Lolli ML, Tron GC, Fruttero R, Gasco A, Deleide G, Guenther HL. Synthesis of NO-Donor Bisphosphonates and Their in-Vitro Action on Bone Resorption. J. Med. Chem. 2005; 48:1322-1329. [PubMed: 15743175]

[84]. Zhang SF, Gangal G, Uludag H. 'Magic bullets' for bone diseases: progress in rational design of bone-seeking medicinal agents. Chem. Soc. Rev. 2007; 36:507-531. [PubMed: 17325789]

[85]. Fleisch HA. Bisphosphonates: Preclinical aspects and use in osteoporosis. Ann. Med. 1997; 29:55-62. [PubMed: 9073324]

[86]. Papapoulos SE, Landman JO, Bijvoet OLM, Lowik C, Valkema R, Pauwels EKJ, Vermeij P. The use of bisphosphonates in the treatment of osteoporosis. Bone. 1992; 13:S41-S49. [PubMed: 1581119]

[87]. Bone HG, Hosking D, Devogelaer J, Tucci JR, Emkey RD, Tonino RP, Rodriguez-Portales JA, Downs RW, Gupta J, Santora AC, Liberman UA, Alendronate Phase IIO. Ten years' experience 
with alendronate for osteoporosis in postmenopausal women. N. Engl. J. Med. 2004; 350:11891199. [PubMed: 15028823]

[88]. Liberman UA, Weiss SR, Broll J, Minne HW, Quan H, Bell NH, Rodriguezportales J, Downs RW, Dequeker J, Favus M, Seeman E, Recker RR, Capizzi T, Santora AC, Lombardi A, Shah RV, Hirsch LJ, Karpf DB. Effect of oral alendronate on bone-mineral density and the incidence of fractures in postmenopausal osteoporosis. N. Engl. J. Med. 1995; 333:1437-1443. [PubMed: 7477143]

[89]. Oura S, Hirai I, Yoshimasu T, Kokawa Y, Sasaki R, Okamura Y. Clinical efficacy of bisphosphonate therapy for bone metastasis from breast cancer. Beast Cancer. 2003; 10:28-32.

[90]. Lolli ML, Rolando B, Tosco P, Chaurasia S, Stilo AD, Lazzarato L, Gorassini E, Ferracini R, Oliaro-Bosso S, Fruttero R, Gasco A. Synthesis and preliminary pharmacological characterisation of a new class of nitrogen-containing bisphosphonates (N-BPs). Bioorg. Med. Chem. 2010; 18:2428-2438. [PubMed: 20299227]

[91]. Baldik Y, Talu U, Altinel L, Bilge H, Demiryont M, Aykac-Toker G. Bone Healing Regulated by Nitric Oxide: An Experimental Study in Rats. Clin. Orthop. Rel. Res. 2002; 404:343-352.

[92]. Holt J, Hertzberg B, Weinhold P, Storm W, Schoenfisch M, Dahners L. Decreasing Bacterial Colonization of External Fixation Pins Through Nitric Oxide Release Coatings. J. Orthop. Trauma. 2011; 25:432-437. 410. 1097/BOT.1090b1013e3181f1099ac1098a. [PubMed: 21637124]

[93]. Madihally SV, Matthew HWT. Porous chitosan scaffolds for tissue engineering. Biomaterials. 1999; 20:1133-1142. [PubMed: 10382829]

[94]. Sudarshan NR, Hoover DG, Knorr D. Antibacterial action of chitosan. Food Biotechnol. 1992; 6:257-272.

[95]. Ravi Kumar M. A review of chitin and chitosan applications. React. Funct. Polym. 2000; 46:127.

[96]. Coester LM, Nepola JV, Allen J, Marsh JL. The Effects of Silver Coated External Fixation Pins. Iowa Orthop J. 2006; 26:48-53. [PubMed: 16789449]

[97]. Charville GW, Hetrick EM, Geer CB, Schoenfisch MH. Reduced bacterial adhesion to fibrinogen-coated substrates via nitric oxide release. Biomaterials. 2008; 29:4039-4044. [PubMed: 18657857]

[98]. Dobmeier KP, Schoenfisch MH. Antibacterial properties of nitric oxide-releasing sol-gel microarrays. Biomacromolecules. 2004; 5:2493-2495. [PubMed: 15530068]

[99]. Nablo BJ, Chen TY, Schoenfisch MH. Sol-gel derived nitric-oxide releasing materials that reduce bacterial adhesion. J. Am. Chem. Soc. 2001; 123:9712-9713. [PubMed: 11572708]

[100]. Nablo BJ, Schoenfisch MH. Antibacterial properties of nitric oxide-releasing sol-gels. J. Biomed. Mater. Res. Part A. 2003; 67A:1276-1283.

[101]. Privett BJ, Nutz ST, Schoenfisch MH. Efficacy of surface-generated nitric oxide against Candida albicans adhesion and biofilm formation. Biofouling. 2010; 26:973-983. [PubMed: 21082455]

[102]. Thomas MV, Puleo DA. Infection, Inflammation, and Bone Regeneration. J. Dent. Res. 2011; 90:1052-1061. [PubMed: 21248364]

[103]. Alvarez, OM.; Goslen, JB.; Eaglstein, WH.; Welgus, HG.; Stricklin, GP. Biology of the dermis: wound healing. In: Fitzpatrick, TB.; Eisen, AZ.; Wolff, K.; Freedber, IM.; Austen, KF., editors. Dermatology in general medicine. McGraw Hill Book Co.; New York: 1987. p. 1-1598.

[104]. Werner S, Grose R. Regulation of wound healing by growth factors and cytokines. Physiol. Rev. 2003; 83:835-870. [PubMed: 12843410]

[105]. Singer AJ, Clark RAF. Mechanisms of disease - Cutaneous wound healing. N. Engl. J. Med. 1999; 341:738-746. [PubMed: 10471461]

[106]. Uitto, J.; Eisen, AZ. Biology of the dermis: collagen. In: Fitzpatrick, TB.; Eisen, AZ.; Wolff, K.; Freedber, IM.; Austen, KF., editors. Dermatology in general medicine. McGraw Hill Book Co.; New York: 1987. p. 1-1598.

[107]. Bauer EA, Uitto J. Collagen in cutaneous diseases. Int. J. Dermatol. 1979; 18:251-270. [PubMed: 222699] 
[108]. Tymvios C, Moore C, Jones S, Solomon A, Sanz-Rosa D, Emerson M. Platelet aggregation responses are critically regulated in vivo by endogenous nitric oxide but not by endothelial nitric oxide synthase. Br. J. Pharmacol. 2009; 158:1735-1742. [PubMed: 19912226]

[109]. Moore C, Tymvios C, Emerson M. Functional regulation of vascular and platelet activity during thrombosis by nitric oxide and endothelial nitric oxide synthase. Thromb. Haemost. 2010; 104:342-349. [PubMed: 20508906]

[110]. Radomski MW, Palmer RMJ, Moncada S. The role of nitric oxide and cGMP in plateletadhesion to vascular endothelium. Biochem. Biophys. Res. Commun. 1987; 148:1482-1489. [PubMed: 2825688]

[111]. Rizk M, Witte MB, Barbul A. Nitric oxide and wound healing. World J.Surg. 2004; 28:301306. [PubMed: 14961192]

[112]. Witte MB, Barbul A. Role of nitric oxide in wound repair. Am. J. Surg. 2002; 183:406-412. [PubMed: 11975928]

[113]. Cooke JP. NO and angiogenesis. Atheroscler. Suppl. 2003; 4:53-60. [PubMed: 14664903]

[114]. Schaffer MR, Efron PA, Thornton FJ, Klingel K, Gross SS, Barbul A. Nitric oxide, an autocrine regulator of wound fibroblast synthetic function. J. Immunol. 1997; 158:2375-2381. [PubMed: 9036987]

[115]. Shi HP, Efron DT, Most D, Barbul A. The role of iNOS in wound healing. Surgery. 2001; 130:225-229. [PubMed: 11490353]

[116]. Obayashi K, Akamatsu H, Okano Y, Matsunaga K, Masaki H. Exogenous nitric oxide enhances the synthesis of type I collagen and heat shock protein 47 by normal human dermal fibroblasts. J. Dermatol. Sci. 2006; 41:121-126. [PubMed: 16171977]

[117]. Witte MB, Thornton FJ, Efron DT, Barbul A. Enhancement of fibroblast collagen synthesis by nitric oxide. Nitric Oxide-Biol. Chem. 2000; 4:572-582.

[118]. Schaffer MR, Tantry U, Thornton FJ, Barbul A. Inhibition of nitric oxide synthesis in wounds: Pharmacology and effect on accumulation of collagen in wounds in mice. Eur. J. Surg. 1999; 165:262-267. [PubMed: 10231662]

[119]. Shi HP, Efron DT, Most D, Tantry US, Barbul A. Supplemental dietary arginine enhances wound healing in normal but not inducible nitric oxide synthase knockout mice. Surgery. 2000; 128:374-378. [PubMed: 10923019]

120. Lee PC, Salyapongse AN, Bragdon GA, Shears LL, Watkins SC, Edington HDJ, Billiar TR. Impaired wound healing and angiogenesis in eNOS-deficient mice. Am. J. Physiol-Heart C. 1999; 277:1600-1608.

[121]. Schaffer MR, Tantry U, Gross SS, Wasserkrug HL, Barbul A. Nitric oxide regulates wound healing. J. Surg. Res. 1996; 63:237-240. [PubMed: 8661204]

[122]. Stallmeyer B, Anhold M, Wetzler C, Kahlina K, Pfeilschifter J, Frank S. Regulation of eNOS in normal and diabetes-impaired skin repair: Implications for tissue regeneration. Nitric Oxide-Biol. Chem. 2002; 6:168-177.

[123]. Yamasaki K, Edington HDJ, McClosky C, Tzeng E, Lizonova A, Kovesdi I, Steed DL, Billiar TR. Reversal of impaired wound repair in iNOS-deficient mice by topical adenoviral-mediated iNOS gene transfer. J. Clin. Invest. 1998; 101:967-971. [PubMed: 9486966]

[124]. Muscara MN, McKnight W, Asfaha S, Wallace JL. Wound collagen deposition in rats: effects of an NO-NSAID and a selective COX-2 inhibitor. Br. J. Pharmacol. 2000; 129:681-686. [PubMed: 10683192]

[125]. Thornton FJ, Schaffer MR, Witte MB, Moldawer LL, MacKay SLD, Abouhamze A, Tannahill CL, Barbul A. Enhanced collagen accumulation following direct transfection of the inducible nitric oxide synthase gene in cutaneous wounds. Biochem. Biophys. Res. Commun. 1998; 246:654-659. [PubMed: 9618268]

[126]. Shekhter AB, Serezhenkov VA, Rudenko TG, Pekshev AV, Vanin AF. Beneficial effect of gaseous nitric oxide on the healing of skin wounds. Nitric Oxide-Biol. Chem. 2005; 12:210-219.

[127]. Hetrick EM, Shin JH, Paul HS, Schoenfisch MH. Anti-biofilm efficacy of nitric oxide-releasing silica nanoparticles. Biomaterials. 2009; 30:2782-2789. [PubMed: 19233464] 
[128]. Shabani M, Pulfer SK, Bulgrin JP, Smith DJ. Enhancement of wound repair with a topically applied nitric oxide-releasing polymer. Wound Repair Regen. 1996; 4:353-362. [PubMed: 17177732]

[129]. Amadeu TP, Seabra AB, Oliveira MG, Costa AMA. S-nitrosoglutathione-containing hydrogel accelerates rat cutaneous wound repair. Nitric Oxide-Biol. Chem. 2006; 14:A52-A52.

[130]. Amadeu TP, Seabra AB, de Oliveira MG, Monte-Alto-Costa A. Nitric oxide donor improves healing if applied on inflammatory and proliferative phase. J. Surg. Res. 2008; 149:84-93. [PubMed: 18374944]

[131]. Evers LH, Bhavsar D, Mailander P. The biology of burn injury. Exp. Dermatol. 2010; 19:777783. [PubMed: 20629737]

[132]. Becker WK, Shippee RL, McManus AT, Mason AD, Pruitt BA. Kinetics of nitrogen-oxide production following experimental thermal-injury in rats. J. Trauma-Injury Infect. Crit. Care. $1993 ; 34: 855-862$.

[133]. Carter EA, Derojaswalker T, Tamir S, Tannenbaum SR, Yu YM, Tompkins RG. Nitric-oxide production is intensely and persistently increased in tissue by thermal-injury. Biochem. J. 1994; 304:201-204. [PubMed: 7528006]

[134]. Paulsen SM, Wurster SH, Nanney LB. Expression of inducible nitric oxide synthase in human burn wounds. Wound Repair Regen. 1998; 6:142-148. [PubMed: 9776857]

[135]. Akcay MN, Ozcan O, Gundogdu C, Akcay G, Balik A, Kose K, Oren D. Effect of nitric oxide synthase inhibitor on experimentally induced burn wounds. J. Trauma-Injury Infect. Crit. Care. 2000; 49:327-330.

[136]. Inoue H, Ando K, Wakisaka N, Matsuzaki K, Aihara M, Kumagai N. Effects of nitric oxide synthase inhibitors on vascular hyperpermeability with thermal injury in mice. Nitric Oxide-Biol. Chem. 2001; 5:334-342.

[137]. Gibran NS, Boyce S, Greenhalgh DG. Cutaneous wound healing. J. Burn Care Res. 2007; 28:577-579. [PubMed: 17665518]

[138]. Zhu HF, Ka B, Murad F. Nitric oxide accelerates the recovery from burn wounds. World J.Surg. 2007; 31:624-631. [PubMed: 17308846]

[139]. Zhu HF, Wei XF, Bian K, Murad F. Effects of nitric oxide on skin burn wound healing. J. Burn Care Res. 2008; 29:804-814. [PubMed: 18695618]

[140]. Schaffer MR, Tantry U, Efron PA, Ahrendt GM, Thornton FJ, Barbul A. Diabetes-impaired healing and reduced wound nitric oxide synthesis: A possible pathophysiologic correlation. Surgery. 1997; 121:513-519. [PubMed: 9142149]

[141]. Le NN, Rose MB, Levinson H, Klitzman B. Implant healing in experimental animal models of diabetes. J. Diabetes. Sci. Technol. 2011; 5:605-618. [PubMed: 21722576]

[142]. Schaffer M, Bongartz M, Fischer S, Proksch B, Viebahn R. Nitric oxide restores impaired healing in normoglycaemic diabetic rats. J. Wound Care. 2007; 16:311-316. [PubMed: 17708383]

[143]. Witte MB, Kiyama T, Barbul A. Nitric oxide enhances experimental wound healing in diabetes. Brit. J. Surg. 2002; 89:1594-1601. [PubMed: 12445072]

[144]. Singh RJ, Hogg N, Joseph J, Konorev E, Kalyanaraman B. The peroxynitrite generator, SIN-1, becomes a nitric oxide donor in the presence of electron acceptors. Arch. Biochem. Biophys. 1999; 361:331-339. [PubMed: 9882464]

[145]. Weller R, Finnen MJ. The effects of topical treatment with acidified nitrite on wound healing in normal and diabetic mice. Nitric Oxide-Biol. Chem. 2006; 15:395-399.

[146]. Mowbray M, Tan XJ, Wheatley PS, Morris RE, Weller RB. Topically applied nitric oxide induces T-Lymphocyte infiltration in human skin, but minimal inflammation. J. Invest. Dermatol. 2008; 128:352-360. [PubMed: 17914444]

[147]. Dashti N, Einollahi N, Zarebavani M, Kiani F. The effect of DETA NONOate, a nitric oxide donor, on the rate of collagen synthesis in rat as an animal model of diabetes. Int. J. Vet. Res. 2010; 4:159-161.

[148]. Li Y, Lee PI. Controlled Nitric Oxide Delivery Platform Based on S-Nitrosothiol Conjugated Interpolymer Complexes for Diabetic Wound Healing. Mol. Pharmaceutics. 2010; 7:254-266. 
[149]. Strachan CJL. The prevention of orthopedic implant vascular graft infections. J. Hosp. Infect. 1995; 30:54-63. [PubMed: 7560996]

[150]. O'Brien M. Functional anatomy and physiology of tendons. Clin. Sport. Med. 1992; 11:505520.

[151]. Andres BM, Murrell GAC. Treatment of tendinopathy: What works, what does not, and what is on the horizon. Clin. Orthop. Rel. Res. 2008; 466:1539-1554.

[152]. Murrell GAC, Szabo C, Hannafin JA, Jang D, Dolan MM, Deng XH, Murrell DF, Warren RF. Modulation of tendon healing by nitric oxide. Inflamm. Res. 1997; 46:19-27. [PubMed: 9117513]

[153]. Tomiosso TC, Nakagaki WR, Gomes L, Hyslop S, Pimentel ER. Organization of collagen bundles during tendon healing in rats treated with L-NAME. Cell Tissue Res. 2009; 337:235242. [PubMed: 19506908]

[154]. Molloy TJ, de Bock CE, Wang Y, Murrell GAC. Gene expression changes in SNAP-stimulated and iNOS-transfected tenocytes - Expression of extracellular matrix genes and its implications for tendon-healing. J. Orthopaed. Res. 2006; 24:1869-1882.

[155]. Xia W, Szomor Z, Wang Y, Murrell GAC. Nitric oxide enhances collagen synthesis in cultured human tendon cells. J. Orthopaed. Res. 2006; 24:159-172.

[156]. Xia W, Wang Y, Appleyard R, Smythe GA, Murrell GAC. Spontaneous recovery of injured Achilles tendon in inducible nitric oxide synthase gene knockout mice. Inflamm. Res. 2006; 55:40-45. [PubMed: 16429255]

[157]. Lin J, Wang MX, Wei A, Zhu W, Murrell GAC. The cell specific temporal expression of nitric oxide synthase isoforms during Achilles tendon healing. Inflamm. Res. 2001; 50:515-522. [PubMed: 11713906]

[158]. Lin JH, Wang MX, Wei AQ, Zhu W, Diwan AD, Murrell GAC. Temporal expression of nitric oxide synthase isoforms in healing Achilles tendon. J. Orthopaed. Res. 2001; 19:136-142.

[159]. Yuan J, Murrell GAC, Wei AQ, Appleyard RC, Del Soldato P, Wang MX. Addition of nitric oxide via nitroflurbiprofen enhances the material properties of early healing of young rat Achilles tendons. Inflamm. Res. 2003; 52:230-237. [PubMed: 12835894]

[160]. Murrell GAC, Tang GY, Appleyard RC, del Soldato P, Wang MX. Addition of nitric oxide through nitric oxide-paracetamol enhances healing rat achilles tendon. Clin. Orthop. Rel. Res. 2008; 466:1618-1624.

[161]. Berrazueta JR, Losada A, Poveda J, Ochoteco A, Riestra A, Salas E, Amado JA. Successful treatment of shoulder pain syndrome due to supraspinatus tendinitis with transdermal nitroglycerin. A double blind study. Pain. 1996; 66:63-67. [PubMed: 8857632]

[162]. Paoloni JA, Appleyard RC, Nelson J, Murrell GAC. Topical nitric oxide application in the treatment of chronic extensor tendinosis at the elbow - A randomized, double-blinded, placebocontrolled clinical trial. Am. J. Sports Med. 2003; 31:915-920. [PubMed: 14623657]

[163]. Paoloni JA, Appleyard RC, Nelson J, Murrell GAC. Topical glyceryl trinitrate treatment of chronic noninsertional achilles tendinopathy - A randomized, double-blind, placebo-controlled trial. J. Bone. Joint. Surg. Am. 2004; 86A:916-922. [PubMed: 15118032]

[164]. Paoloni JA, Appleyard RC, Nelson J, Murrell GAC. Topical glyceryl trinitrate application in the treatment of chronic supraspinatus tendinopathy - A randomized, double-blinded, placebocontrolled clinical trial. Am. J. Sports Med. 2005; 33:806-813. [PubMed: 15827365]

[165]. Paoloni JA, Murrell GAC. Three-year followup study of topical glyceryl trinitrate treatment of chronic noninsertional Achilles tendinopathy. Foot Ankle Int. 2007; 28:1064-1068. [PubMed: 17923056]

[166]. Kane TPC, Ismail M, Calder JDF. Topical glyceryl trinitrate and noninsertional Achilles tendinopathy - A clinical and cellular investigation. Am. J. Sports Med. 2008; 36:1160-1163. [PubMed: 18359821]

[167]. McCallum SDA, Paoloni JA, Murrell GAC. Five-year prospective comparison study of topical glyceryl trinitrate treatment of chronic lateral epicondylosis at the elbow. Br. J. Sports Med. 2011; 45:416-420. [PubMed: 19553221] 
[168]. Paoloni JA, Murrell GAC, Burch RM, Ang RY. Randomised, double-blind, placebo-controlled clinical trial of a new topical glyceryl trinitrate patch for chronic lateral epicondylosis. Br. J. Sports Med. 2009; 43:299-302. [PubMed: 18971247]

[169]. Ignarro LJ, Lippton H, Edwards JC, Baricos WH, Hyman AL, Kadowitz PJ, Gruetter CA. Mechanism of vascular smooth-muscle relaxation by organic nitrates, nitrites, nitroprusside and nitric oxide - Evidence for the involvement of S-nitrosothols as active intermediates. J. Pharmacol. Exp. Ther. 1981; 218:739-749. [PubMed: 6115052]

[170]. Park JW. Reaction of S-nitrosoglutathione with sulfhydryl-groups in protein. Biochem. Biophys. Res. Commun. 1988; 152:916-920. [PubMed: 3284528]

[171]. Ewing JF, Young DV, Janero DR, Garvey DS, Grinnell TA. Nitrosylated bovine serum albumin derivatives as pharmacologically active nitric oxide congeners. J. Pharmacol. Exp. Ther. 1997; 283:947-954. [PubMed: 9353418] 


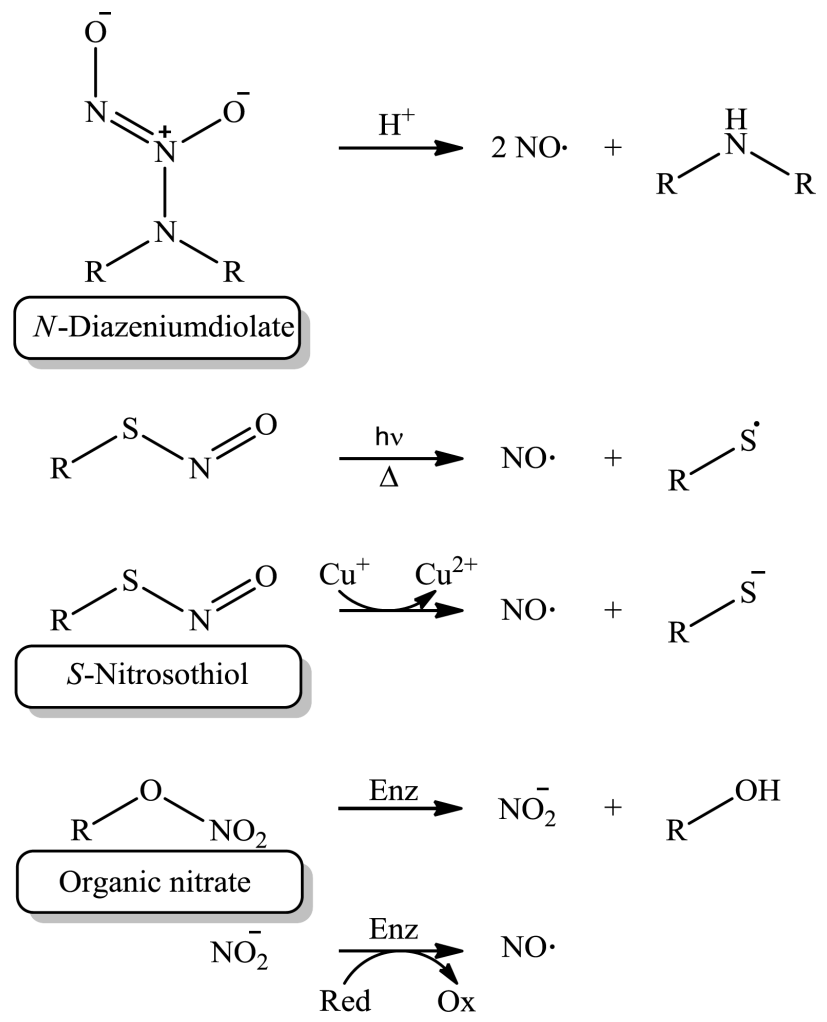

Figure 1.

Primary NO-release mechanisms for three major classes of NO donors ( $N$ diazeniumdiolates, $S$-nitrosothiols, and organic nitrates). 


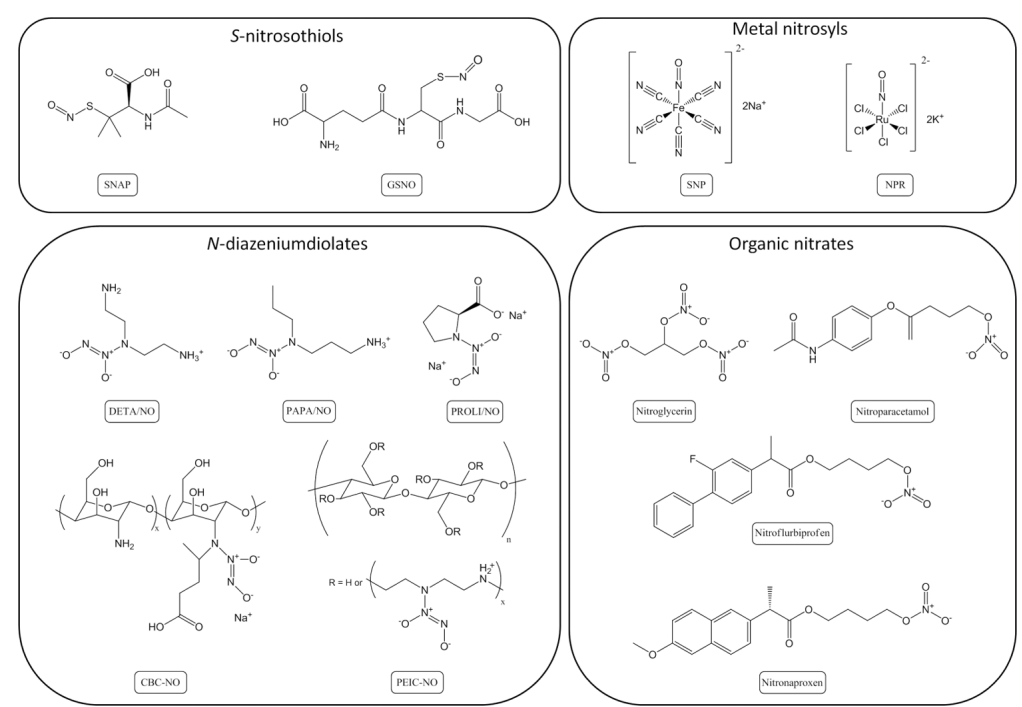

Figure 2.

Structures of NO donors used to supply NO exogenously in biological studies. 


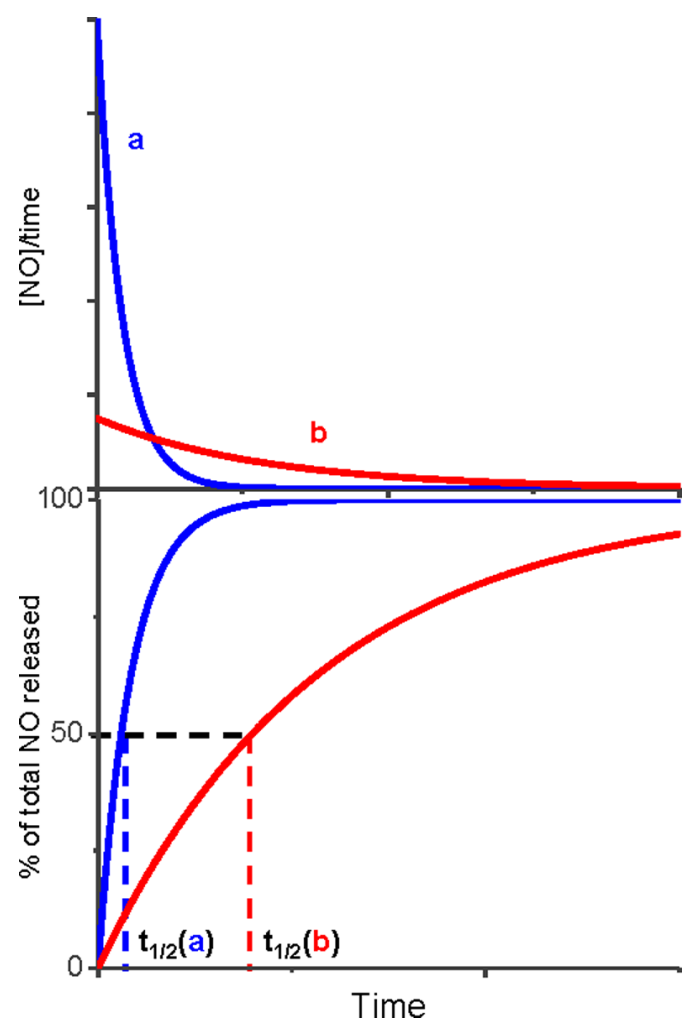

Figure 3.

Nitric oxide-release half-lives from parent donor species predict release rate. Donor (b) has a half-life 5 times greater than donor (a). Assuming first order kinetics and equal donor concentrations, sustained NO-release durations will be longer for compound (b), but maximum NO concentrations will be higher for compound (a). 

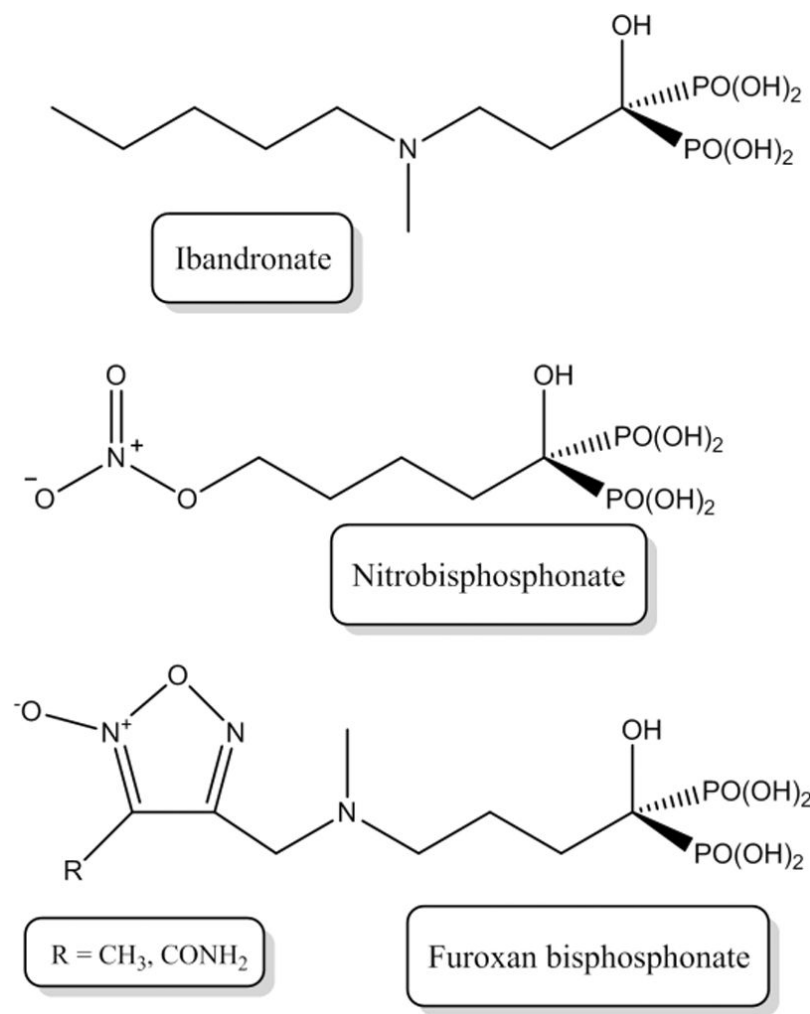

Figure 4.

Structures of a clinical bisphosphonate, ibandronate, along with a nitrobisphosphonates synthesized by Lazzarato et al. [83]. The bisphosphonate functionality along with the hydroxyl group allow the bisphosphonate to bind effectively to bone while the organic nitrate functionality confers $\mathrm{NO}$ release. 


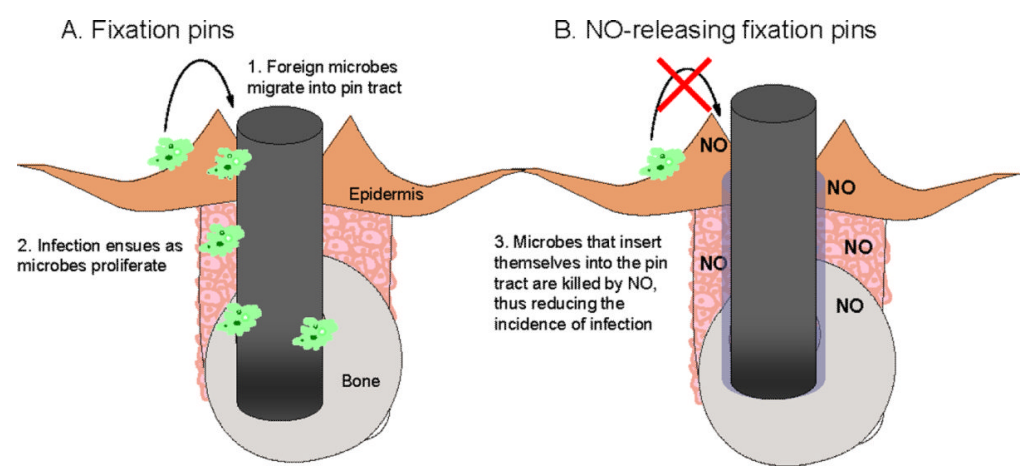

Figure 5.

External fixation pins coated with NO-releasing xerogels impart antimicrobial action to pin surfaces, thus acting as a biocide against microbes that migrate into the pin tract. 


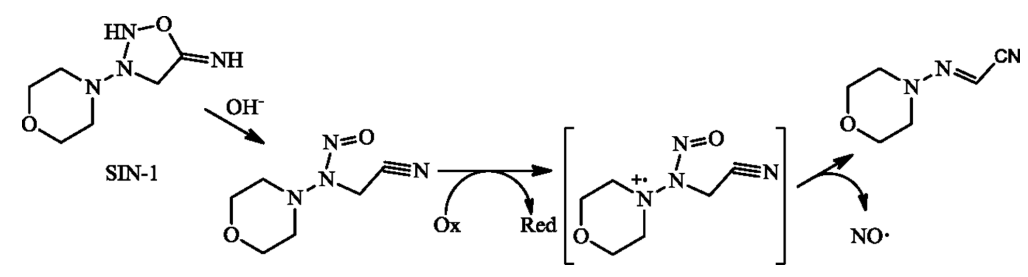

Figure 6.

Release of NO from SIN-1, the hepatic product of molsidomine, occurs via this proposed mechanism [144]. 
Table 1

Nitric oxide release data from $\mathrm{NO}$ donors.

\begin{tabular}{|c|c|c|c|c|}
\hline NO donor & Donor type & NO release half-life & Experimental parameters & Total NO $\left(\mu \mathrm{mol} \mathrm{mg}^{-1}\right)$ \\
\hline PROLI/NO & $N$-diazeniumdiolate & $1.8 \mathrm{~s}[16]$ & $\mathrm{pH} 7.4,37^{\circ} \mathrm{C}$ & $7.97^{a}$ \\
\hline DETA/NO & $N$-diazeniumdiolate & $20 \mathrm{~h}[16]$ & $\mathrm{pH} 7.4,37^{\circ} \mathrm{C}$ & $12.25^{a}$ \\
\hline PAPA/NO & $N$-diazeniumdiolate & $15 \min [16]$ & $\mathrm{pH} 7.4,37^{\circ} \mathrm{C}$ & $11.35^{a}$ \\
\hline $\mathrm{CBC}-\mathrm{NO}$ & $N$-diazeniumdiolate & $31 \min ^{b}[47]$ & $\mathrm{pH} 7.4,37^{\circ} \mathrm{C}$ & $0.05[47]$ \\
\hline PEIC-NO & $N$-diazeniumdiolate & $16 \mathrm{~h}[128]$ & $\mathrm{pH} 7.4,37^{\circ} \mathrm{C}$ & $0.0685[128]$ \\
\hline SNAP & $S$-nitrosothiol & $1.7 \mathrm{~h}[169]$ & $\mathrm{pH} 7,37^{\circ} \mathrm{C}, 50 \mathrm{mM}$ tris- $\mathrm{HCl}, 10 \mathrm{mM}$, in dark & $4.54^{a}$ \\
\hline GSNO & $S$-nitrosothiol & $3 \mathrm{~h}^{c}[170]$ & $\mathrm{pH} 7.4,37^{\circ} \mathrm{C}$, in dark & $2.97^{a}$ \\
\hline SNO-BSA & $S$-nitrosothiol & $5 \mathrm{~h}[91]$ & $\mathrm{pH} 7.4,37^{\circ} \mathrm{C}, 0.3 \mathrm{mM}$, in dark & $0.227[171]$ \\
\hline Nitroglycerin & Organic nitrate & $\mathrm{N} / \mathrm{A}^{d}$ & & $13.21^{a}$ \\
\hline Nitroparacetamol & Organic nitrate & $\mathrm{N} / \mathrm{A}^{d}$ & & $3.57^{a}$ \\
\hline Nitroflurbiprofen & Organic nitrate & $\mathrm{N} / \mathrm{A}^{d}$ & & $2.77^{a}$ \\
\hline Nitronaproxen & Organic nitrate & $\mathrm{N} / \mathrm{A}^{d}$ & & $2.88^{a}$ \\
\hline SNP & Metal nitrosyl & $\mathrm{N} / \mathrm{A}^{d}$ & & $3.82^{a}$ \\
\hline NPR & Metal nitrosyl & $\mathrm{N} / \mathrm{A}^{d}$ & & $2.59^{a}$ \\
\hline
\end{tabular}

${ }^{a}$ Theoretical total NO release based on chemical structure

${ }^{b}$ Approximated by assuming first-order kinetics and 6 half-lives (95\% decay)

${ }^{c}$ Calculated from second order rate constant with $5 \mathrm{mM}$ GSNO

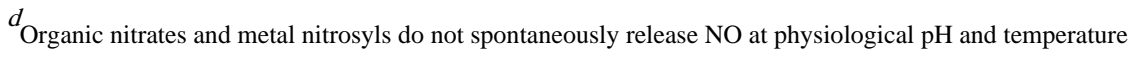

